20

\title{
Активные формы кислорода в водных средах (06зор)
}

\author{
(C) Л.В. Беловолова \\ Институт общей фризики им. А.М. Прохорова РАН, \\ 119991 Москва, Россия \\ e-mail:est123321@mail.ru
}

Поступила в редакцию 31.01.2020 г.

В окончательной редакции 26.02.2020 г.

Принята к публикации 28.02.2020 г.

Рассмотрены проблемы, связанные с присутствием активных форм кислорода (АФК) в природных водных средах и живых организмах. Приведены основные свойства АФК, которые обеспечивают особенности их поведения. Основное внимание сосредоточено на анализе данных о состоянии водных систем с несколько повышенным содержанием АФК по сравнению с равновесными значениями.

Ключевые слова: вода, атмосферные газы, активные формы кислорода и воды, коллективные явления.

DOI: $10.21883 /$ OS.2020.07.49565.64-20

\section{Введение}

Проблемы, связанные с поведением активных форм кислорода и воды (АФК) в биологических объектах и водных средах, затрагивают широкий круг вопросов на стыке физики, химии, биологии и медицины [1-10], возможно поэтому история их исследований имеет много драматичных моментов. Биологические последствия проявления АФК выявились после открытия радиоактивности и попыток ее использования на практике, хотя само понятие АФК появилось много позднее. Несмотря на долгую историю исследований процессов с участием АФК, до настоящего времени имеются „белые пятна“ в понимании особенностей их проявления. Огромный пласт проблем, касающийся роли АФК в живых системах как в норме, так и при патологиях, является бурно развивающейся областью биохимии и медицины. Он отражен во множестве оригинальных работ и обзоров. В настоящей работе основное внимание будет сосредоточено на поведении системы АФК в разбавленных водных средах. Особенности поведения АФК в живых клетках будут описаны кратко и только в объеме, необходимом для понимания основ их взаимодействия с водным окружением. Практически каждый раздел настоящей работы можно сильно углублять, рассматривая результаты многочисленных современных работ. Однако при этом есть риск затруднить восприятие общей картины проблем в целом, поскольку большинство работ только уточняют уже сложившиеся представления. Важнее показать тенденции развития исследований водных систем с учетом присутствия в них АФК. До сих пор многие особенности поведения АФК в „чистой“ воде являются неожиданными, поэтому требуют детального анализа всех условий. Но с годами накапливается все больше данных, показывающих, что особенности взаимодействия атмосферных газов и АФК с водным окружением определяют многие нетипичные свойства водных систем. И они требуют пересмотра привычных химических представлений о молекулярных взаимодействиях в воде в условиях низкого содержания примесей. По-видимому, в разбавленных водных средах на первый план выходят коллективные явления, приводящие к структурным и динамическим перестройкам водной матрицы, в которых АФК являются главными управляющими элементами. Цель настоящей работы - дать введение в проблемы взаимодействия АФК и воды.

Активные формы кислорода во всех живых организмах производятся и быстро убираются многоуровневыми ферментными системами. Они могут переходить из одной формы в другую и существовать то в виде свободных радикалов, то в виде соединений, не обладающих электронным спином. Из первых важнейшими являются супероксидный $\left(\mathrm{O}_{2}^{\bullet-}\right)$ или в протонированной форме - гидроперекисный $\left(\mathrm{HO}_{2}^{-}\right)$и гидроксильный $\left(\mathrm{OH}^{\bullet}\right)$ радикалы. Из вторых - озон $\left(\mathrm{O}_{3}\right)$, синглетный кислород $\left({ }^{1} \mathrm{O}_{2}\right)$ и перекись водорода $\left(\mathrm{H}_{2} \mathrm{O}_{2}\right)$ [1-10]. Активные формы кислорода могут порождать, регулировать и обрывать цепные реакции [11]. Поскольку радикалы АФК, как правило, короткоживущие, то об их появлении обычно судят по увеличению содержания перекиси водорода или органических пероксидов, которые появляются в результате дисмутации (рекомбинации) радикалов. В биосистемах перекись водорода способна через поры проникать в мембрану клеток и выступать как вторичный мессенджер [12].

В природных водах АФК образуются благодаря наличию радиационного фона Земли и воздействию различных природных и техногенных факторов. По оценкам А.М. Кузина [13] только благодаря наличию радиационного фона Земли в $1 \mathrm{~cm}^{3}$ воды в секунду происходит $10^{4}$ актов образования ионизованных состояний и $3 \cdot 10^{4}$ 
возбужденных. Большинство из образовавшихся частиц сразу же соединяются в исходную молекулу, а избыток энергии рассеивается в виде тепла, однако присутствие во всех природных водах $\mathrm{H}_{2} \mathrm{O}_{2}$ показывает, что образование АФК имеет место. Это наблюдение говорит и о том, что вода постоянно может находиться в возбужденном состоянии.

Активные формы кислорода вступают в окислительновосстановительные реакции с молекулами примесей, в том числе с атмосферными газами и ионами металлов. В природных водах с их помощью дезактивируются многие токсические вещества [14]. Наибольшее значение для образования и развития процессов с участием АФК в природных водах имеют гуминовые соединения. У всех гуминовых веществ есть ароматический углеродный скелет с активными группами. Их периферическая часть обогащена полисахаридными и полипептидными фрагментами. Гуминовые соединения способны к обратимым окислительно-восстановительным превращениям, значимым для природных экосистем [15].

Проблематику АФК условно можно разделить на два класса: первый относится к исследованиям химических процессов в биологических системах разных уровней организации от клеточных органелл до целостных многоклеточных организмов. Этот класс работ имеет относительно давнюю историю и очень бурно развивается, в особенности в медицинских аспектах [16-19]. Второй класс охватывает круг проблем, касающихся исследований физико-химических механизмов взаимодействия АФК с окружением в воде и разбавленных водных средах. Его развитие началось в самом конце прошлого и начале текущего веков. В настоящее время все большее внимание исследователей привлекают неожиданные свойства разбавленных водных сред, как, например, чувствительность к энергетически слабым воздействиям или долговременные колебательные процессы хемилюминесценции воды после лазерного облучения.

\section{Биологические и химические проблемы AФK}

Биологические и химические проблемы АФК обусловлены тем обстоятельством, что в основе метаболизма любого организма лежит баланс между системой антиоксидантной защиты (AO3) и прооксидантной системой (ПОС), важнейшие звенья которых протекают с участием АФК. Системы АОЗ и ПОС в совокупности образуют сложный иерархический узел окислительно-восстановительных процессов с положительными и отрицательными обратными связями, в результате которых в клетках постоянно генерируются свободные радикалы [1-13,1622]. Их регулируют самые мощные и многоуровневые ферментные системы организма, что указывает на их исключительную важность для жизни клетки. Например, скорость ферментов супероксиддисмутазы (СОД) и каталазы превышает $10^{6} \mathrm{~s}^{-1}$. Супероксиддисмутаза катализирует реакцию дисмутации двух супероксидных радикалов с образованием $\mathrm{H}_{2} \mathrm{O}_{2}$ и кислорода, а каталаза разлагает $\mathrm{H}_{2} \mathrm{O}_{2}$ до кислорода и воды. Интересно, что оба эти фермента могут инактивироваться субстратами друг друга, причем эта инактивация представляет собой не просто „выключение“ фермента, а приводит к изменению путей взаимопревращения АФК. В литературе отмечается [23], что СОД и каталаза могут восстанавливать свою ферментативную активность до

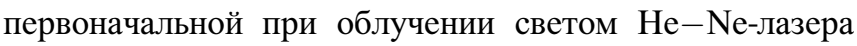
$(\lambda=632 \mathrm{~nm})$.

Нарушение баланса в образовании АФК под действием внешних или внутренних факторов ведет либо к изменению режима функционирования, либо к развитию патологий [1-9,16-22]. При патологиях происходит усиление свободнорадикальных процессов, нарушение баланса между ПОС и АОЗ и снижение буферной емкости систем АОЗ. В результате усиливается перекисное окисление липидов биологических мембран клетки и возникает так называемый окислительный стресс. Усиление перекисного окисления липидов сверх нормального уровня изменяет вязкость, текучесть, проницаемость и другие параметры мембран, запускает каскад $\mathrm{Ca}^{2+}$-зависимых реакций, ведущих к разобщению окислительного фосфорилирования, включению ферментов каскада арахидоновой кислоты и глубоким изменениям метаболизма клетки. На начальных стадиях эти процессы являются обратимыми, а вследствие наличия отрицательных обратных связей в системе АФК могут даже увеличивать уровень антиоксидантов. После наступления необратимых стадий активируются лизосомальные ферменты, что приводит к уничтожению клеток.

Свободнорадикальные реакции с участием АФК в патологических процессах изучаются сравнительно давно, поскольку АФК являются первичными частицами, обнаруживающимися в клетке при различных повреждениях. Они играют важную роль в процессах апоптоза (запрограммированной гибели клетки), воспалительных состояниях, злокачественном перерождении клеток, различных патологиях, вызванных действием проникающей радиации, ультрафиолетового и лазерного облучения, мутагенов различной природы и т. д. [1-22]. Долгое время господствовали представления, что задача каждой клетки - не допустить утечки АФК, постоянно образующихся в ферментативных процессах. Поскольку некоторая утечка происходит всегда, то считалось, что именно это приводит к старению клетки за счет накопления поломок и нарушений, вызванных окислением важнейших компонентов клетки („свободно радикальная теория старения“). До сих пор стараются замедлить старение организма искусственным снижением уровня АФК [2427]. Однако доказано, что воздействия, приводящие к генерации АФК и в больших дозах вызывающие нарушения, в малых дозах оказывают стимулирующее, нормализующее и протекторное влияние [12,27-32]. Более того, 
хотя концентрация радикалов супероксида в воздухе ничтожна (порядка нескольких сотен частиц в $\mathrm{cm}^{3}$ ), их полное удаление приводит к гибели экспериментальных животных в течение нескольких дней $[27,28,32]$. Обогащение воздуха супероксидом до концентрации $10^{4} \mathrm{~cm}^{-3}$ нормализует состояние организма, приводя в порядок давление крови и ее реологию, улучшая оксигенацию тканей и усиливая общую резистентность организма к стрессовым факторам. Определенный уровень содержания АФК абсолютно необходим, поскольку действие первичных мессенджеров (гормонов, цитокинов, нейротрансмиттеров) происходит либо через активацию процессов генерации АФК, либо через ингибирование системы АO3 [33-35].

В нормальных клетках выработка АФК происходит ритмически, а все другие клеточные процессы с нею синхронизованы [36,37]. Так, в индивидуальных гранулоцитах, где АФК генерируются NADPH-оксидазами, вся совокупность этих ферментов „включается“ на $20 \mathrm{~s}$, a в следующие $20 \mathrm{~s}$ клетка выполняет другие функции. В клетках из септической крови эта ритмичность нарушена. Колебательные режимы излучения фотонов характерны не только для отдельных клеток, но и для суспензий нейтрофилов [37] и даже для цельной неразведенной крови [38]. Существенно, что наблюдаемые колебания носят сложный, многоуровневый характер. Периоды колебаний лежат в диапазоне от десятков минут до их долей. Ритмы с участием АФК, возникающие в организме, в той или иной степени зависят и от внешних водителей ритма, например, от колебаний внешних электромагнитных и магнитных полей.

Концентрация АФК может возрастать в некоторые моменты жизнедеятельности клетки, и эти изменения коррелируют с определенными физиологическими процессами. Перехват АФК химическими ловушками в этих условиях приводит к определенным клеточным нарушениям [20].

В реакции АФК вовлечены окислы азота [39-41] и ионы бикарбоната [42-45], играющие важнейшие роли в клеточном метаболизме. Эти процессы сильно зависят от присутствия и окислительно-восстановительного состояния металлов (таких как железо, марганец, медь, молибден, цинк, кальций, редкие земли и других), белков и аминокислотных остатков, присутствующих в клетке. Кроме того, реакции с участием радикалов и между радикальными парами зависят от поверхности раздела фаз [46], поэтому физико-химические особенности клеточной мембраны и приповерхностных слоев воды могут либо катализировать, либо ингибировать эти процессы [47].

Процессы с участием АФК имеют место во всех живых клетках. В том числе АФК являются важным звеном в организации мозговой активности. Клетки мозга балансируют на грани предельно допустимого уровня свободных радикалов $[6,7,12,48,49]$, осуществляющих важные регуляторные функции в нейронах, поэтому в этих тканях имеет место неустойчивое равновесие между образованием и нейтрализацией свободных радикалов. Для мозга характерен повышенный синтез простагландинов, тромбоксанов и лейкотриенов. Эти процессы требуют участия $\mathrm{O}_{2}^{\bullet-}$ и арахидоновой кислоты, высвобождающейся из мембранных фосфолипидов в ходе перекисного окисления. Мозг человека, составляющий лишь $2 \%$ от массы его тела, потребляет около $20 \%$ получаемого организмом кислорода и страдает в первую очередь при недостатке АФК во вдыхаемом воздухе [27,28,32].

Реакции между свободными радикалами и дезактивация их возбужденных состояний обычно сопровождаются излучением света. В экспериментах АФК могут возбуждаться и детектироваться методами флуоресценции [50,51], хемилюминесценции [52], электро- и триболюминесценции [53,54], при кавитации в газовых пузырьках [55], в турбулентных потоках жидкости [56], при электромагнитных воздействиях [57,58]. Проблемы оптических излучений биологических объектов, связанные с генерацией возбужденных состояний АФК, имеют давнюю историю, начиная еще с классических работ А.Г. Гурвича по исследованию митогенетического излучения [59]. Однако до сих пор полностью неясна их роль в клеточном метаболизме, хотя уже накопилось достаточно экспериментального материала, свидетельствующего о связи характеристик излучения клеток с их физиологическим состоянием. Все клетки, имеющие ядра, светятся с разной интенсивностью от единиц квантов в минуту до многих тысяч. Свечение клеток в первую очередь обусловлено образованием и рекомбинацией свободных радикалов при перекисном окислении липидов клетки [60-67]. При патологиях интенсивность свечения резко увеличивается, а длина волны света изменяется. Некоторые лекарственные соединения сильно меняют параметры излучений клетки [23]. В настоящее время еще присутствует мнение, что излучение света является лишь побочным эффектом свободнорадикальных процессов, не играющим функционально значимой роли, однако есть данные, позволяющие предполагать, что ритмически протекающие во всех живых клетках процессы генерации высокоэнергетических электронновозбужденных состояний могут иметь принципиальное значение [68].

\section{Активные формы кислорода в воде и сильно разбавленных водных средах}

Активные формы кислорода в воде и сильно разбавленных водных средах в настоящее время активно исследуются. Важно отметить, что первоначальные исследования физико-химических механизмов взаимодействия АФК с водным окружением были инициированы биологическими экспериментами, показавшими, что эффекты, возникающие в клеточных культурах при повышении 
содержания АФК, могут быть получены при аналогичных воздействиях на чистую воду, которую после некоторого времени задержки используют для приготовления питательной среды для этой культуры [2931]. Механизмы „памяти“ такого влияния на воду в течение нескольких часов после прекращения внешнего воздействия до настоящего времени не находят удовлетворительного объяснения в рамках традиционных химических представлений, однако наличие биологического эффекта дает основание для поиска механизмов его реализации.

В равновесных условиях концентрация наиболее стабильного и легко уловимого вида АФК-перекиси водорода-в клетках и природных водах оценивается на уровне $0.1 \mu \mathrm{M} / 1$, а содержание радикалов АФК еще на несколько порядков ниже $[8,25,69]$. При различных воздействиях концентрации АФК в водных средах могут повышаться, но обычно остаются слишком низкими для их непосредственного измерения, поэтому в течение долгого времени о процессах с их участием можно было судить только по биологическим проявлениям, влиянию различных тушителей люминесценции или изменению параметров химических ловушек, меняющихся под влиянием АФК [70]. Например, хемилюминесцентными маркерами образования АФК служат люминол и люцигенин. В отличие от люминола люцигенин специфичен для $\mathrm{O}_{2}^{\bullet-}$. Для регистрации $\mathrm{H}_{2} \mathrm{O}_{2}$, появляющейся в результате дисмутации $\mathrm{OH}^{\bullet}$ и $\mathrm{HO}_{2}^{\bullet}$, используют пероксидазу хрена. Концентрации используемых ловушек обычно на порядки превосходят стационарные концентрации радикалов, поэтому они могут сами оказывать преимущественное влияние на состояние водной среды. Тем не менее эксперименты с использованием ловушек АФК позволили установить, что различные физические воздействия на водную среду, в том числе слабые и низкоэнергетические, могут приводить к повышению содержания $\mathrm{H}_{2} \mathrm{O}_{2}$ или органических пероксидов. В дальнейшем с повышением чувствительности экспериментальных методов появилась возможность исследовать процессы с участием АФК в воде без дополнительных добавок. Было показано, что после различных воздействий, например, при фотохимическом возбуждении [71-74], небольшом нагреве $[75,76]$, при кавитации [55], в турбулентных потоках $[56,57]$ в водных системах проявляются долговременные (часы и сутки) релаксационные процессы, в том числе и колебательного характера. Например, через несколько часов после пятиминутного лазерного облучения воды возникают колебания хемилюминесцентного сигнала, продолжающиеся десятки часов [71] (рис. 1). Излучение водной среды после возбуждения может иметь вид отдельных мощных вспышек флуоресцентного сигнала при $\lambda_{\mathrm{ex}}=250-310 \mathrm{~nm}$ (рис. 2,3) [74] или высокую интенсивность сигнала вне полос флуоресценции растворенного пигмента [72,73]. Так, на рис. 1-3 показаны типичные виды излучений после лазерной (рис. 1) или электрохимической (рис. 2 и 3) обработки водных систем. Динамика состояния воды после прекращения

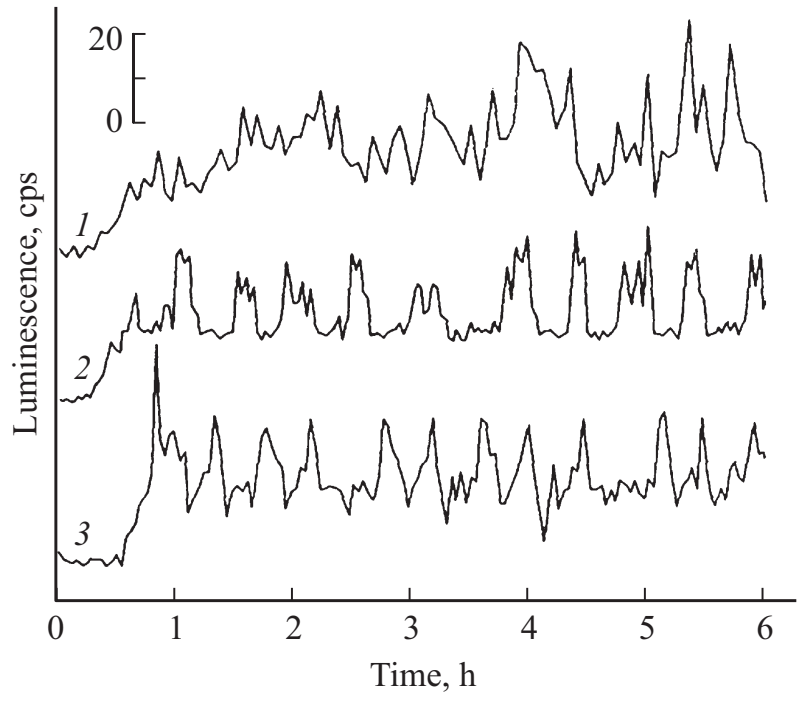

Рис. 1. Основные типы осцилляций хемилюминесценции воды, возникающей через несколько часов после 5 min облучения воды $\mathrm{He}-\mathrm{Ne}$-лазером [71].

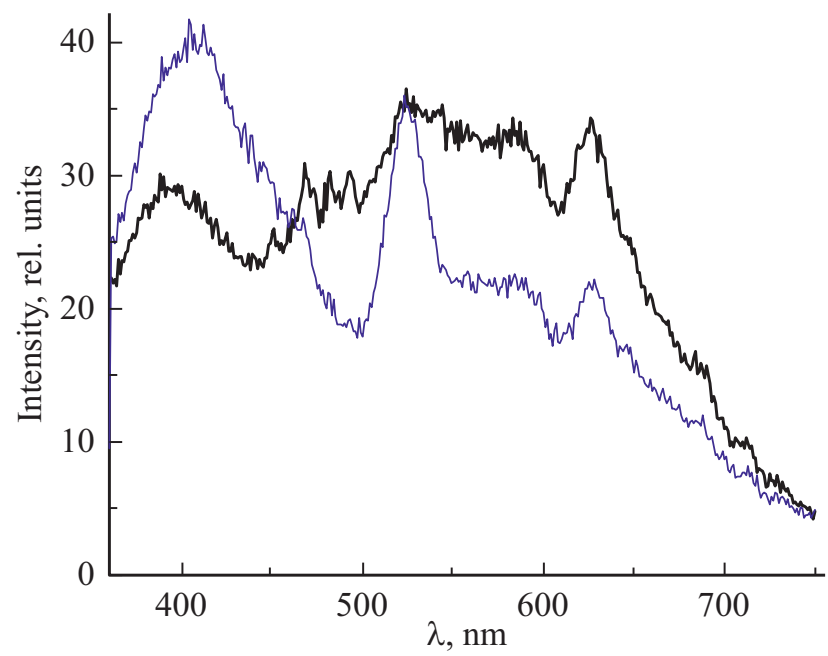

Рис. 2. Типичные спектры флуоресценции $\left(\lambda_{\mathrm{ex}}=260 \mathrm{~nm}\right)$ как католита, так и анолита [74] очищенной водопроводной воды без добавок, наблюдаемые в некоторые моменты времени после электролиза.

внешнего воздействия может быть весьма сложной и часто плохо воспроизводимой, поскольку вода с растворенными в ней атмосферными газами, подобно живому организму, является открытой неравновесной системой, постоянно обменивающейся с окружением массой и энергией.

Такая система может быть чрезвычайно чувствительной к предыстории водного образца, контакту с атмосферой, наличию и виду малых примесей, а также к рутинным лабораторным процедурам (отбору проб, встряхиванию, переливанию ит.п.), что может приводить к большим разбросам параметров, в особенности измеряемых в разное время и разных лабораториях. 

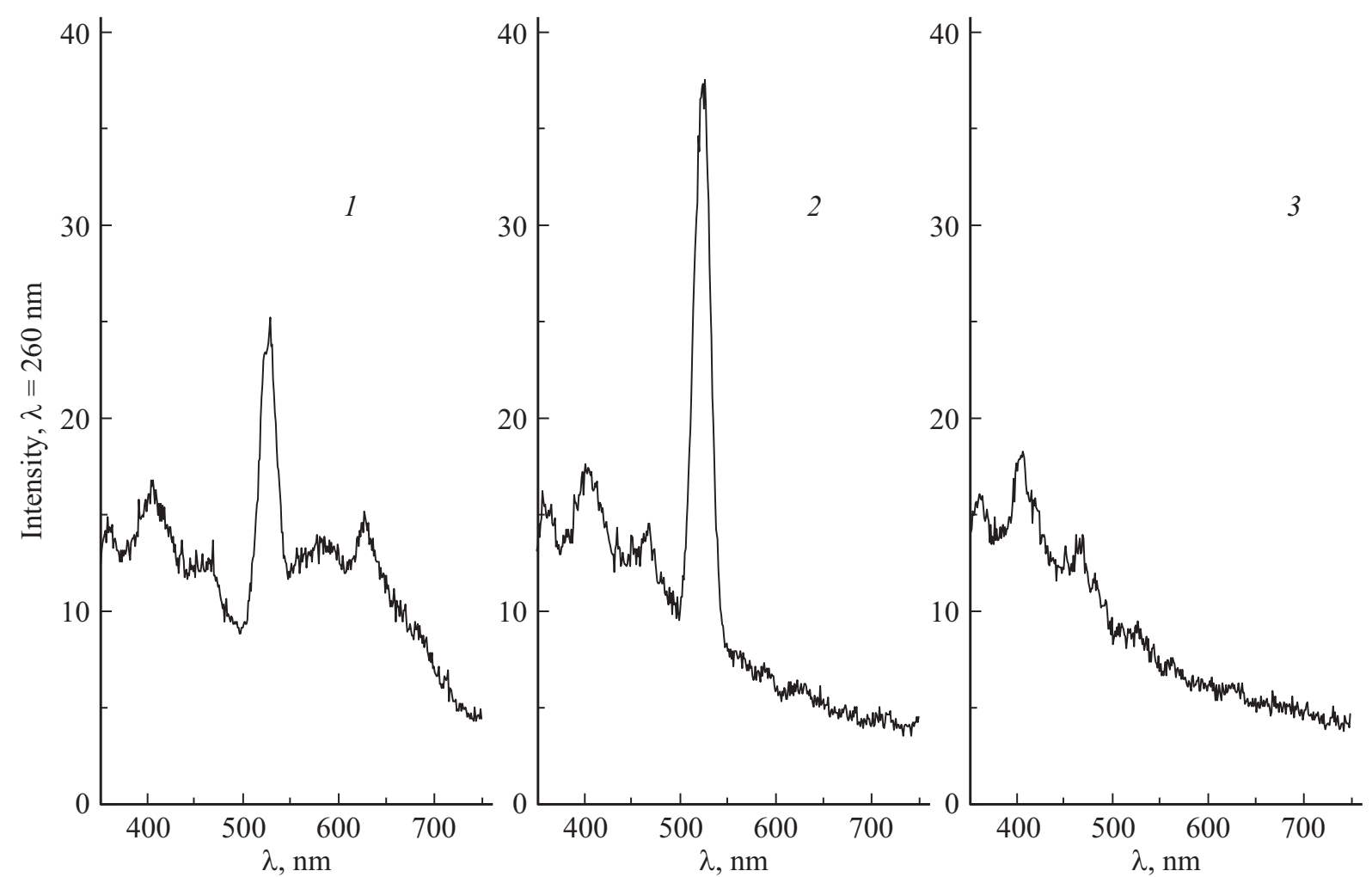

Рис. 3. Типичные спектры флуоресценции $\left(\lambda_{\mathrm{ex}}=260 \mathrm{~nm}\right)$ анолита после электролиза воды с добавками хлористого натрия в анодный отсек через $10(1), 130$ (2) и 300 (3) min после электролиза [74].

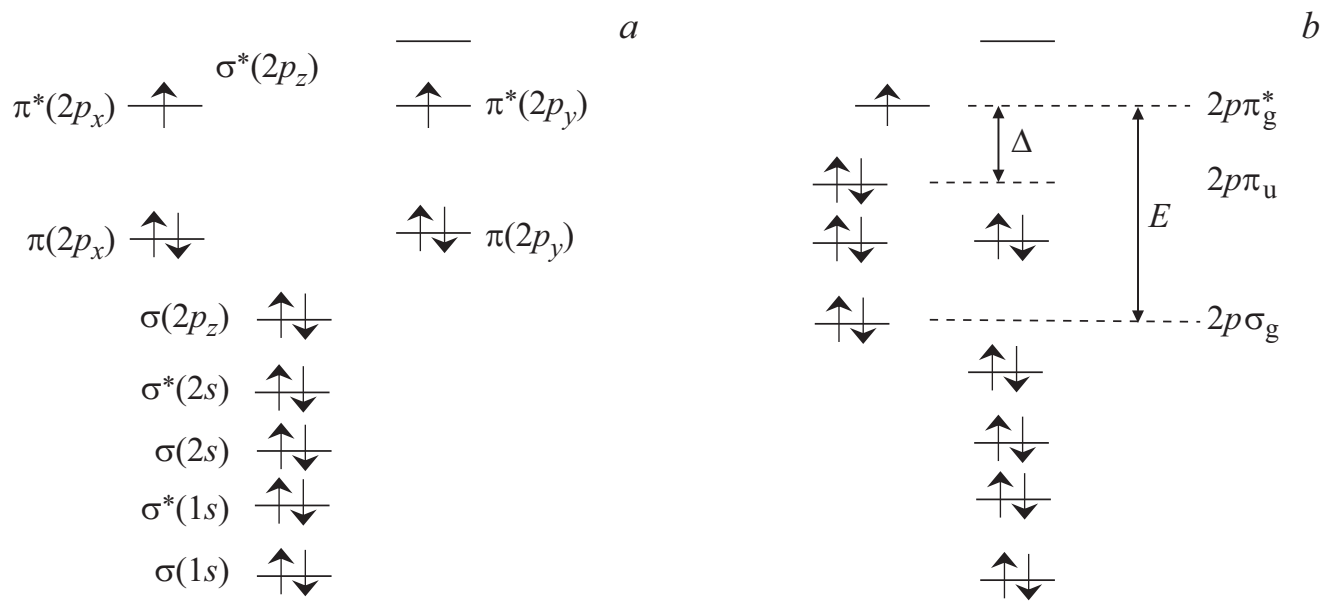

Рис. 4. Схема электронных уровней молекул $\mathrm{O}_{2}(a)$ и $\mathrm{O}_{2}^{\bullet-}(b)[80]$.

Например, установлено, что в „чистой“ воде есть относительно длительные периоды (часы), когда ее параметры сохраняются, и есть времена быстрых изменений к другим значениям, также сохраняющимся длительное время. Наличие примесей и дополнительной обработки увеличивает частоту таких скачков [74,77]. Эти факторы сделали исследования воды и сильно разбавленных водных сред весьма сложными, однако особенности, связанные с присутствием атмосферных газов, были обнаружены.
Для химических процессов с участием АФК характерно наличие положительных и отрицательных обратных связей, а также стадий относительно медленного накопления и быстрого распада перекисных продуктов, в результате чего в таких системах могут возникать химические колебательные процессы типа Белоусова-Жаботинского [78]. Они могут приводить к появлению большого набора пространственно распределенных неравновесных динамических структур и „триггерных волн““ переключения между состояниями системы. В процессах 
с участием АФК водная среда является не просто инертной матрицей, способной поставлять и аккумулировать протоны и электроны, а служит активным элементом формирования определенных состояний сложной взаимосвязанной системы АФК-паровоздушные пузырькиводное окружение [79]. В связи с этим основная часть настоящей работы посвящена рассмотрению особенностей взаимодействия АФК и атмосферных газов с водой и границами раздела фаз. Но сначала проведем краткий обзор свойств АФК, которые обеспечивают их уникальное взаимодействие между собой и водным окружением.

\section{Электронная структура АФК}

Процессы с участием АФК и их реакционная способность определяются особенностями электронной структуры этих молекул. Молекула кислорода, как и атомарный кислород, в основном состоянии парамагнитна. Ее свойства определяются двумя электронами на высших орбиталях (рис. 4, a) [80].

Присоединение одного электрона к молекуле кислорода (образование иона супероксида) ведет к заполнению высшей не полностью занятой разрыхляющей орбитали $2 p \pi_{g}^{*}$, в результате чего молекула $\mathrm{O}_{2}^{\bullet-}$ оказывается менее стабильной, чем $\mathrm{O}_{2}$. Спектральные и магнитные свойства $\mathrm{O}_{2}^{\bullet-}$ объясняются простейшей схемой молекулярных орбиталей, приведенной на рис. $4, b$. Поскольку ион $\mathrm{O}_{2}^{\bullet-}$ образован добавлением к молекуле кислорода одного электрона на верхнюю разрыхляющую орбиталь $2 p \pi_{g}^{*}$, это вызывает ян-теллеровское возмущение, приводящее к расщеплению этого уровня. Парамагнетизм $\mathrm{O}_{2}^{\bullet-}$ обусловлен неспаренным электроном на верхнем уровне $2 p \pi_{g}^{*}$. Величина $\Delta$ определяется ионным окружением (рис. $4, b)$ молекулы и сильно зависит от растворителя, а также взаимодействия с ионами металлов.

Ион $\mathrm{O}_{2}^{\bullet-}$ сильно взаимодействует с протонами, организуя вокруг себя молекулы воды [80]. Именно поэтому его характеристики (в частности, время жизни) сильно различаются в протонных и апротонных растворителях. Взаимодействие $\mathrm{HO}_{2}^{\bullet}$ с молекулой воды приводит к образованию состояния $\mathrm{O}_{2}^{\bullet \bullet \bullet} \mathrm{H}_{3} \mathrm{O}^{+}$, в котором $\mathrm{O}_{2}$ обнаруживается в возбужденном синглетном состоянии [81]. Спектр ЭПР иона $\mathrm{O}_{2}^{\bullet-}$ в воде при комнатной температуре не наблюдается, однако его протонированная форма $\mathrm{HO}_{2}^{\bullet}$ имеет при комнатной температуре сигнал ЭПР с шириной $27 \mathrm{G}$. Ее связывание с диамагнитными ионами металлов в их наивысшем окислительном состоянии сильно сужает спектр, который становится характерным для свободных радикалов в жидкой фазе. Эти комплексы довольно устойчивы $\left(K>10^{3} \mathrm{M}^{-1}\right)$ [80].

Основным состоянием молекулы кислорода является триплетное состояние ${ }^{3} \Sigma_{g}^{-}$. Более высоко лежащие по энергии конфигурации соответствуют синглетным состояниям ${ }^{1} \Delta_{g}$ и ${ }^{1} \Sigma_{g}^{+}$(рис. 5). Они выше основного состояния на 23.5 и $37.5 \mathrm{kcal} / \mathrm{mol}$ соответственно.

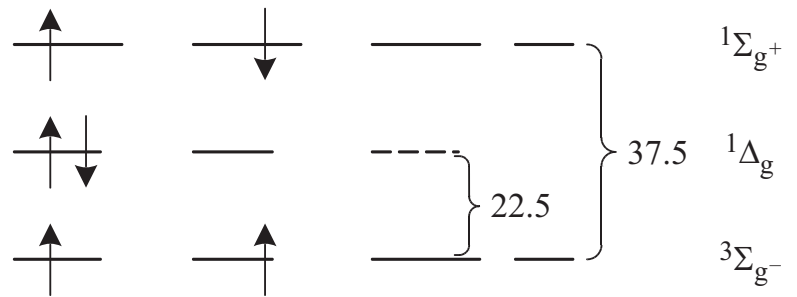

Рис. 5. Простейшая схема верхних уровней молекулы кислорода в основном триплетном $\left({ }^{3} \Sigma_{g}^{-}\right)$и возбужденных синглетных состояниях $1 \Delta_{g}$ и ${ }^{1} \Sigma_{g}^{+}[91]$.

Двухэлектронное восстановление молекулы кислорода дает пероксид-анион $\mathrm{O}_{2}^{2-}$ (в протонированной форме $\left.\mathrm{HO}_{2}^{-}\right)$и $\mathrm{H}_{2} \mathrm{O}_{2}$. Гидроксильный радикал $\mathrm{OH}^{\bullet}$ представляет собой электро-нейтральную половину молекулы перекиси водорода или атом кислорода, присоединивший атом водорода.

В пероксидном ионе одинарная $\sigma$-связь О-O относительно слабая и может разрываться с образованием двух ОН-радикалов (что легко достигается поглощением кванта света).

\section{Окислительно-восстановительные потенциалы активных форм кислорода}

Окислительно-восстановительный потенциал (редокспотенциал - $\left.E_{0}\right)$ АФК, в частности $\mathrm{O}_{2}^{\bullet}$ и $\mathrm{H}_{2} \mathrm{O}_{2}$, сильно зависит от полярности окружения и $\mathrm{pH}$ водного раствора, поэтому может значительно отличаться от стандартного [82,83]. Принятое среднее значение $E_{0}$ иона супероксида в несольватирующих апротонных растворителях составляет $-0.57 \mathrm{~V}$. В газовой фазе и апротонных растворителях супероксид довольно устойчив и является хорошим восстановителем, способным быть электронным донором для многих соединений. Экспериментальные значения редокс-потенциала в различных апротонных растворителях по данным разных авторов составляют от -0.49 до $-0.65 \mathrm{~V}$. В воде при $\mathrm{pH} 7.0$ при взаимодействии с хинонами и цитохромом $C$ потенциал супероксида составляет от -0.27 до $-0.33 \mathrm{~V}$. Обычно принимают значение стандартного потенциала супероксида в воде равным $-0.33 \mathrm{~V}$. В водном растворе супероксид легко восстанавливает цитохром $C$, что сопровождается значительными изменениями спектра поглощения последнего, поэтому в экспериментальных работах цитохром $C$ используют как эффективную и удобную ловушку для супероксида. Есть предположение, что эта реакция важна в защите клетки от АФК, рожденных в митохондриях при осмотическом шоке, вызванном окислительным стрессом [26].

Стандартный потенциал супероксида в воде близок к потенциалу пары NAD/NADH2 $\left(E_{0}=-0.32 \mathrm{~V}\right.$ при $\mathrm{pH}$ 7.0), что, по-видимому, имеет значение в регуляции процессов электронного переноса в дыхательной 
цепи митохондрий. В то же время, поскольку редокспотенциал супероксида значительно изменяется в зависимости от окружения, можно предполагать, что круг окислительно-восстановительных процессов с его участием может быть много шире из-за взаимодействия с границами раздела фаз и примесями.

Изменение потенциала супероксида при переходе от апротонных растворителей к воде обусловлено сильной гидратацией молекулы супероксида. Средний редокспотенциал аниона супероксида в органических растворителях на $0.26 \mathrm{~V}$ ниже, чем в водном растворе, поэтому при его переносе из органической фазы в водную выделяется энергия $\sim 6 \mathrm{kcal} / \mathrm{mol}$. Сильная сольватация молекулы супероксида в воде влияет на его нуклеофильность: он становится худшим восстановителем и может быть окислителем некоторых соединений. В апротонном растворителе диметилформамиде он может жить многие часы, а в воде быстро протонируется и превращается в перекись водорода при взаимодействии двух таких частиц.

Принято считать, что при рН ниже 4.8 супероксид присутствует в водном растворе практически полностью в протонированной форме, а выше 4.8 - в непротонированной. Максимумы поглощения и коэффициенты экстинкции составляют $230 \mathrm{~nm}, \varepsilon=1200 \mathrm{M}^{-1} \mathrm{~cm}^{-1}$ и $245-250 \mathrm{~nm}, \varepsilon=2000 \mathrm{M}^{-1} \mathrm{~cm}^{-1}$ для $\mathrm{HO}_{2}^{\bullet}$ и $\mathrm{O}_{2}^{\bullet-}$ соответственно $[8,80]$.

\section{Образование АФК в воде при импульсном фотолизе или радиолизе}

Суть процессов с участием АФК в воде можно пояснить на примере разложения воды методами радиационной химии, поскольку вода как растворитель давно используется для изучения механизмов химических реакций методами импульсного фотолиза и радиолиза [84]. Ионизирующее излучение образует возбужденные молекулы воды $\mathrm{H}_{2} \mathrm{O}^{*}$, катион-радикалы воды $\mathrm{H}_{2} \mathrm{O}^{+}$и свободные электроны $\mathrm{e}^{-}$за время, меньшее $10^{-15} \mathrm{~s}$. Электроны термализуются и сольватируются за время порядка $10^{-12} \mathrm{~s}$. Сольватированный электрон $\left(\mathrm{e}_{\mathrm{aq}}^{-}\right)$в воде имеет характерный спектр поглощения в области $720 \mathrm{~nm}$. Катион-радикалы $\mathrm{H}_{2} \mathrm{O}^{+}$отбирают протон у молекул воды с образованием $\mathrm{OH}^{*}$-радикала и иона гидроксония $\mathrm{H}_{3} \mathrm{O}^{+}$за время $\left(1.6 \cdot 10^{-14} \mathrm{~s}\right)$, меньшее времени рекомбинации $\mathrm{H}_{2} \mathrm{O}^{+}$и $\mathrm{e}^{-}$. Очень быстрая диссоциация возбужденных молекул воды приводит к образованию атома водорода $\mathrm{H}^{\cdot}$ и гидроксильного радикала $\mathrm{OH}$.

В недегазированном водном растворе электрон и атом водорода эффективно взаимодействуют с молекулой кислорода с образованием молекулы супероксида:

$$
\begin{gathered}
\mathrm{e}_{\mathrm{aq}}^{-}+\mathrm{O}_{2} \rightarrow \mathrm{O}_{2}^{-}, \\
\mathrm{H}^{\bullet}+\mathrm{O}_{2} \rightarrow \mathrm{HO}_{2}^{-}, \\
\mathrm{HO}_{2}^{\dot{ }} \leftrightarrow \mathrm{H}^{+}+\mathrm{O}_{2}^{--} .
\end{gathered}
$$

Состояние пары $\mathrm{HO}_{2} / \mathrm{O}_{2}$ в водной среде сильно зависит от $\mathrm{pH} \mathrm{c} \mathrm{pK}_{\mathrm{a}} \sim 4.7-4.8$. Радикалы $\mathrm{HO}_{2}$ дисмутируют с образованием $\mathrm{H}_{2} \mathrm{O}_{2}$ и молекулы кислорода в возбужденном синглетном состоянии $\left({ }^{1} \mathrm{O}_{2}^{*}\right)$ :

$$
\mathrm{HO}_{2}^{*}+\mathrm{HO}_{2} \rightarrow \mathrm{H}_{2} \mathrm{O}_{2}+{ }^{1} \mathrm{O}_{2}^{*}+h v .
$$

В молекуле $\mathrm{H}_{2} \mathrm{O}_{2}$ связываются два протона, поэтому по мере нарастания ее концентрации по реакции (4) $\mathrm{pH}$ раствора растет. Это означает, что с ростом $\mathrm{pH}$ образование $\mathrm{H}_{2} \mathrm{O}_{2}$ будет замедляться.

Процесс накопления $\mathrm{H}_{2} \mathrm{O}_{2}$ ограничивается ее самопроизвольным или стимулированным распадом. Так, с ростом $\mathrm{pH}$ она распадается с подкислением среды

$$
\mathrm{H}_{2} \mathrm{O}_{2} \leftrightarrow \mathrm{HO}_{2}^{-}+\mathrm{H}^{+}\left(\mathrm{pK}_{\mathrm{a}} \sim 11.5\right) .
$$

$\mathrm{C}$ ростом содержания $\mathrm{H}_{2} \mathrm{O}_{2}$ восстановитель - ион $\mathrm{O}_{2}^{\bullet-}$ способствует ее лавинообразному разложению и образованию сильнейшего окислителя $-\mathrm{OH}^{\bullet}$ [85]:

$$
\begin{gathered}
\mathrm{H}_{2} \mathrm{O}_{2}+\mathrm{O}_{2}^{\bullet-} \rightarrow \mathrm{OH}^{-}+\mathrm{OH}^{\bullet}+\mathrm{O}_{2}, \\
\mathrm{OH}^{\bullet}+\mathrm{H}_{2} \mathrm{O}_{2} \rightarrow \mathrm{HO}_{2}^{\bullet}+\mathrm{H}_{2} \mathrm{O}
\end{gathered}
$$

Скорость этой реакции сильно зависит от присутствия ионов железа или меди [85]. Исторически сложилось, что знакомство исследователей с $\mathrm{O}_{2}^{\bullet-}$ произошло в условиях, когда его малые концентрации вызывали лавинообразное разложение $\mathrm{H}_{2} \mathrm{O}_{2}$ с образованием ОН-радикала. Вследствие реакций (6) и (7), обычно наблюдающихся в состояниях окислительного стресса в различных патологиях, супероксидный радикал получил свое название, не всегда соответствующее его свойствам.

Перекись водорода также может самопроизвольно разлагаться под действием света или при катализе ионами металлов (главным образом ионами железа и меди в реакции Фентона [86]):

$$
\mathrm{H}_{2} \mathrm{O}_{2}+h v \rightarrow 2 \mathrm{OH}^{\bullet}
$$

Эта реакция протекает по сложному многостадийному механизму [86].

В периодическом накоплении и разложении перекиси водорода может заключаться суть периодических процессов появления и исчезновения излучений, наблюдающихся в воде после различных воздействий, влияющих на систему АФК.

\section{Окислительные и восстановительные реакции АФК}

В импульсных методах исследования химических реакций обычно создают условия, когда образуются либо окислительные, либо восстановительные виды АФК [84]. Для устранения $\mathrm{OH}^{\bullet}$-радикала в раствор обычно вводят формиат натрия, который перехватывает $\mathrm{OH}^{\bullet}$-радикал и образует радикал $\mathrm{CO}_{2}^{-}$, являющийся восстановителем, 
Таблица 1. Электронные состояния молекулы кислорода

\begin{tabular}{|c|c|c|c|c|c|}
\hline \multirow{2}{*}{$\begin{array}{c}\text { Электронное } \\
\text { состояние }\end{array}$} & \multicolumn{2}{|c|}{ Время жизни, s } & \multirow{2}{*}{$\begin{array}{c}\text { Относительная } \\
\text { энергия, kcal/mol }\end{array}$} & \multirow{2}{*}{$\begin{array}{c}\text { Положение } \\
0-0 \text {-полосы, } \lambda, \mathrm{nm}\end{array}$} & \multirow{2}{*}{$\begin{array}{c}\text { Равновесное } \\
\text { расстояние О-О, } \AA\end{array}$} \\
\hline & Вакуум & Водный раствор & & & \\
\hline $\begin{array}{c}{ }^{1} \Sigma_{g}^{+} \\
{ }^{1} \Delta_{g} \\
{ }^{3} \Sigma_{g}^{-}\end{array}$ & $\begin{array}{c}7 \\
2700 \\
\infty\end{array}$ & $\begin{array}{c}\sim 10^{-11} \\
\sim 10^{-6} \\
\infty\end{array}$ & $\begin{array}{c}37.51 \\
22.53 \\
0\end{array}$ & $\begin{array}{c}762.14 \\
1268.7 \\
-\end{array}$ & $\begin{array}{l}1.227 \\
1.216 \\
1.207\end{array}$ \\
\hline
\end{tabular}

который далее реагирует с кислородом с образованием анион-радикала супероксида. Подобную роль могут выполнять многие карбонатные соединения, в частности ион бикарбоната, в который при нормальных условиях переходит примерно половина молекул растворенного в воде углекислого газа (см. ниже). Таким образом окислительное состояние водной среды заменяется на восстановительное. Следует отметить, что рекомбинация карбонатных радикалов сопровождается оптическими излучениями с высоким квантовым выходом [87]. Для создания окислительных условий при радиолизе водного раствора реакцию ведут в присутствии закиси азота, хотя и другие окислы азота оказывают аналогичное действие. Взаимодействие супероксидного радикала и окиси азота приводит к образованию сильного окислителя пероксинитрита $\mathrm{NOOO}^{-}, \mathrm{OH}^{-}$-радикала и синглетного кислорода, в результате чего окислительные процессы развиваются лавинообразно. Само появление $\mathrm{OH}^{\prime}$-радикала в воде способствует образованию окислов азота из кислорода и азота воздуха $[88,89]$. Взаимодействие иона супероксида и окиси азота протекает по-разному в зависимости от присутствия иона бикарбоната [39-41]. Эти особенности имеют большое значение в биохимии клетки.

\section{Основные физико-химические параметры синглетного кислорода $\left({ }^{1} \mathrm{O}_{2}^{*}\right)$}

Появление АФК в водных средах возможно не только путем возбуждения и разложения молекулы воды, но и за счет возбуждения молекулы газообразного кислорода, растворенного в воде, на что требуется энергия в $\sim 1 \mathrm{eV}$. Синглетный кислород образуется в реакции дисмутации супероксида, разложения пероксинитрита и образования перекиси водорода, причем его выход сильно зависит от природы растворителя. В химических системах ${ }^{1} \mathrm{O}_{2}^{*}$ получают разложением озонидов, перекисей различных ароматических углеводородов и в других реакциях разложения [90]. Возбужденные состояния молекул пигментов тушатся кислородом, растворенным в водной среде клеток, в результате чего рождаются АФК, в первую очередь в виде ${ }^{1} \mathrm{O}_{2}^{*}$. Это явление лежит в основе фотодинамического эффекта [91] — разрушительного действия света в присутствии кислорода и сенсибилизирующих красителей на биологические объекты. Он обнаружен для всех классов живых существ и широко используется в фотодинамической терапии опухолей.

Эффекты ${ }^{1} \mathrm{O}_{2}^{*}$ снимаются в присутствии $\beta$-каротина, который является хорошим тушителем его флуоресценции [90]. Тушение происходит по динамическому механизму путем столкновения молекул. Образование синглетного кислорода в форме ${ }^{1} \Delta_{g}$ или ${ }^{1} \Sigma_{g}^{+}$зависит от энергии триплетного состоянии фотосенсибилизатора $\left(E_{m}\right)$. При высоких значениях Еm образование синглетного кислорода в форме $\mathrm{O}_{2}\left({ }^{1} \Sigma_{g}^{+}\right)$выгоднее, чем в форме $\mathrm{O}_{2}\left({ }^{1} \Delta_{g}\right)$, так как при этом наименьшее количество электронной энергии переходит в колебательную.

Некоторые параметры возбужденных состояний молекулы кислорода приведены в табл. 1 и 2. Уточнения длин волн переходов ${ }^{1} \mathrm{O}_{2}^{*}$ при некоторых условиях приведены в [92,93]. Молекула ${ }^{1} \mathrm{O}_{2}^{*}$ люминесцирует с очень низким квантовым выходом. В водном растворе квантовый выход флуоресценции $\mathrm{O}_{2}\left({ }^{1} \Delta_{g}\right)$ на длине волны $1.27 \mu \mathrm{m}$ составляет не более $10^{-10}$ и соответствует сильно запрещенному переходу.

Состояние $\mathrm{O}_{2}\left({ }^{1} \Sigma_{g}^{+}\right)$намного более короткоживущее (табл. 1), и хотя эмиссия с него менее затруднена, квантовый выход эмиссии из этого состояния не превышает $10^{-12}$. Время жизни возбужденного состояния ${ }^{1} \mathrm{O}_{2}^{*}$ меньше всего в гидроксилсодержащих растворителях. В воде оно составляет около $2 \mu \mathrm{s}$. В тяжелой воде время жизни увеличивается на порядок. Этот факт часто используется в экспериментах для установления участия ${ }^{1} \mathrm{O}_{2}^{*}$ в исследуемых процессах. Возможно, что ${ }^{1} \mathrm{O}_{2}^{*}$ может разменивать избыток колебательной энергии по ОНсвязям воды, увеличивая, таким образом, интенсивность их колебаний (см. ниже). В воздухе и апротонных растворителях время жизни его возбужденного состояния много больше.

Обнаружено, что антитела в водной среде клетки могут генерировать $\mathrm{H}_{2} \mathrm{O}_{2}$ непосредственно из ${ }^{1} \mathrm{O}_{2}^{*}$ [94]. Полагают, что это происходит за счет образования и распада комплексов молекул ${ }^{1} \mathrm{O}_{2}^{*}$ и воды [94-96]. Полагают также, что в определенных условиях вода, упорядоченная этими белками, приобретает свойства восстановителя [96].

На рис. 6 показаны важнейшие связи между молекулами АФК. Красным цветом показаны стандартные потенциалы в нормальных условиях [9].

Важной особенностью ${ }^{1} \mathrm{O}_{2}^{*}$ и $\mathrm{O}_{3}$ является высокоэффективная способность вступать в реакции по двойным 


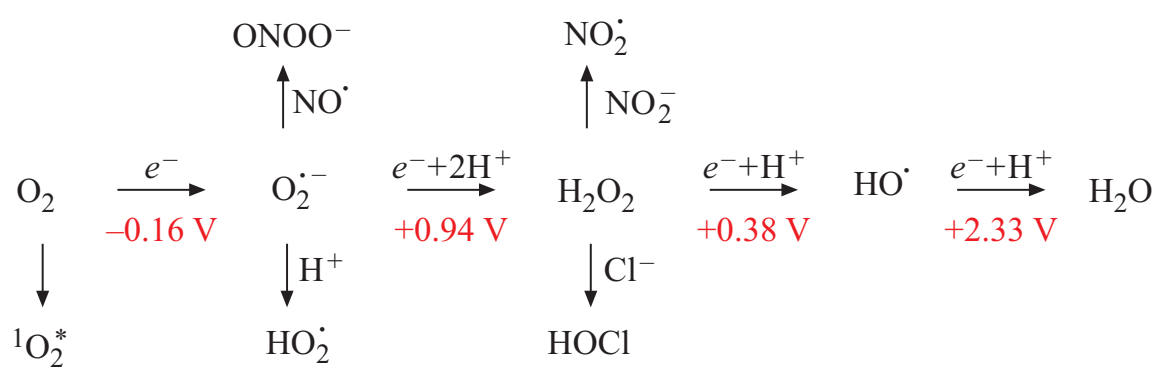

Рис. 6. Соотношения между важнейшими компонентами АФК [9].

Таблица 2. Максимумы полос поглощения и люминесценции возбужденных состояний кислорода в газовой фазе

\begin{tabular}{c|c}
\hline \multicolumn{1}{c|}{ Переход } & Максимум полосы, $\mathrm{nm}$ \\
\hline $\mathrm{O}_{2}\left({ }^{1} \Delta_{g}\right) \rightarrow \mathrm{O}_{2}\left({ }^{3} \Sigma_{g}^{-}\right)$ & 1270 \\
$\mathrm{O}_{2}\left({ }^{1} \Sigma_{g}^{+}\right) \rightarrow \mathrm{O}_{2}\left({ }^{3} \Sigma_{g}^{-}\right)$ & 762 \\
$2 \mathrm{O}_{2}\left({ }^{1} \Delta_{g}\right) \rightarrow 2 \mathrm{O}_{2}\left({ }^{3} \Sigma_{g}^{-}\right)+h v$ & 634,703 \\
$2 \mathrm{O}_{2}\left({ }^{1} \Sigma_{g}^{+}\right) \rightarrow 2 \mathrm{O}_{2}\left({ }^{3} \Sigma_{g}^{-}\right)+h v$ & $381,361,478$
\end{tabular}

связям в соединениях высокой электронной плотности с образованием 1,2-диоксиэтанов [22,97], которые разлагаются до карбонилсодержаших фрагментов, причем значительная доля их может быть в возбужденном состоянии. Энергия возбуждения может высвечиваться непосредственно или быть перенесена на другие флуоресцирующие молекулы.

Главная особенность реакций с участием АФК их чрезвычайно высокий энергетический выход, достаточный для генерации электронно-возбужденных состояний. Так, при разложении молекулы $\mathrm{H}_{2} \mathrm{O}_{2}$ до воды освобождается $2 \mathrm{eV}$. При полном одноэлектронном восстановлении одной молекулы $\mathrm{O}_{2}$ до воды освобождается $8 \mathrm{eV}$ (для сравнения энергия УФ фотона с длиной волны $250 \mathrm{~nm}$ равна $5 \mathrm{eV}$ ). По мнению В. Воейкова $[62,68,96]$ лавинообразное образование возбужденных состояний может формировать своеобразные биоэнергетические потоки, необходимые для запуска, поддержания и упорядочивания разнообразных биохимических и физиологических процессов. Колебательный режим таких реакций может обусловливать ритмичное протекание биохимических процессов более высокого уровня. Именно в процессах с участием АФК происходит самоорганизация, проявляющаяся в ритмическом освобождении фотонов.

\section{Особенности реакций АФК в разбавленных водных средах}

\section{Равновесные концентрации атмосферных газов в воде}

В табл. 3 приведены концентрации некоторых молекул, содержащихся в $1 \mathrm{~cm}^{3}$ чистой не дегазированной воды в нормальных условиях [74]. Как указано выше, в процессах с участием АФК в воде важную роль способны играть производные углекислого газа и азота воздуха. Ионы $\mathrm{HCO}_{3}^{-}$устраняют из воды ОН-радикалы и приводят к накоплению молекул анион-радикала супероксида. Тем самым окислительные условия преобразуются в восстановительные. Например, по данным работы [86] имеет место следующая система процессов:

$$
\begin{gathered}
\mathrm{OH}^{\bullet}+\mathrm{HCO}_{3}^{-} \rightarrow \mathrm{CO}_{3}^{\bullet-}+\mathrm{H}_{2} \mathrm{O} \quad\left(k=4 \cdot 10^{7} \mathrm{M}^{-1} \mathrm{~s}^{-1}\right), \\
\mathrm{CO}_{3}^{\bullet-}+\mathrm{OH}^{\bullet} \rightarrow \mathrm{CO}_{2}+\mathrm{HO}_{2}^{-} \quad\left(k=3 \cdot 10^{9} \mathrm{M}^{-1} \mathrm{~s}^{-1}\right), \\
\mathrm{CO}_{3}^{\bullet-}+\mathrm{H}_{2} \mathrm{O}_{2} \rightarrow \mathrm{HCO}_{3}^{-}+\mathrm{HO}_{2}^{\bullet} \quad\left(k=8 \cdot 10^{5} \mathrm{M}^{-1} \mathrm{~s}^{-1}\right)
\end{gathered}
$$

Гидроксильный радикал способствует образованию окислов азота из атмосферного азота [88,89]. В их присутствии устраняются продукты с восстановительной тенденцией, а окислители накапливаются лавинообразно [98]. Так реализуется окислительное состояние системы. В частности, этот эффект лежит в основе образования фотохимического смога [99]. Таким образом, состояние водной среды может определяться не только концентрацией и видом первичных радикалов, но и балансом окислов азота и карбонатных соединений. Из табл. 3 можно видеть, что в нормальных условиях концентрация протонов в воде на три порядка ниже концентрации растворенного кислорода. Концентрация ионов бикарбоната, в который превращается примерно половина молекул растворенного углекислого газа при нормальных условиях, на порядок превышает концентрацию диссоциированных молекул воды. Поэтому проводимость чистой воды определяется главным образом растворением углекислого газа. Эта величина может колебаться, поскольку ионы бикарбоната вступают в реакции с АФК. Известно, что барботирование газообразным азотом дистиллированной воды, находящейся в равновесии с воздухом, резко понижает ее проводимость [100]. К подобному эффекту приводит и дегазация воды [101] из-за удаления ионов бикарбоната. Содержание перекиси также может заметно меняться в зависимости от различных воздействий на воду.

\section{Электролиз воды и водных растворов}

Для исследования особенностей водных систем с повышенным содержанием АФК перспективна обработка 
Таблица 3. Содержание некоторых молекул в жидкой воде при нормальных условиях

\begin{tabular}{c|c|c|c|c|c|c|c}
\hline Молекула & $\mathrm{H}_{2} \mathrm{O}$ & $\mathrm{H}^{+}, \mathrm{OH}^{-}$ & $\mathrm{H}_{2} \mathrm{O}_{2}$ & $\mathrm{O}_{2}$ & $\mathrm{CO}_{2}$ & $\mathrm{HCO}_{3}^{-}$ & $\mathrm{N}_{2}$ \\
\hline $\begin{array}{c}\text { Концентрация, } \\
\text { molecule/cm }\end{array}$ & $3 \cdot 10^{22}$ & $1 \cdot 10^{14}$ & $1 \cdot 10^{13}$ & $1 \cdot 10^{17}$ & $\begin{array}{c}2 \cdot 10^{15} \\
(\mathrm{pH} 5.7-5.9)\end{array}$ & $1 \cdot 10^{15}$ & $3 \cdot 10^{17}$
\end{tabular}

воды электролизом с раздельными объемами водной среды около катода и анода, поскольку при этом возможно различение эффектов от АФК в разных окислительно-восстановительных состояниях. Несмотря на то, что при электролизе водных сред протекают различные химические реакции в зависимости от наличия примесей, материала сосуда и электродов, в катодном отделении электролизера (католите) первоначально образуются АФК с восстановительной тенденцией, а в анодном отделении (анолите) - АФК с окислительной тенденцией [102,103]. Величина $\mathrm{pH}$ католита смещается в щелочную область, а $\mathrm{pH}$ анолита - в кислую, редокспотенциал католита уменьшается, а анолита повышается относительно этих характеристик исходной воды. Измененные значения параметров католита и анолита медленно релаксируют к значениям исходной воды, но сильно отличаются от них в течение по крайней мере нескольких суток.

Восстановление протона в католите приводит к появлению атома водорода $\mathrm{H}^{\bullet}$, обладающего неспаренным электроном, а молекула газообразного водорода получается в результате реакции между двумя свободными радикалами - атомами водорода:

$$
\mathrm{H}^{\bullet}+\mathrm{H}^{\bullet} \rightarrow \mathrm{H}_{2}
$$

Эта реакция сильно зависит от скорости образования атомов водорода и свойств поверхности электрода и прилегающих слоев растворителя. Для протекания любой реакции между двумя радикалами, в которой продукт образуется в синглетном состоянии, необходимым условием является противоположная ориентация спинов радикалов в момент столкновения. Ориентирующее действие поверхности электрода и адсорбированного слоя зарядов может значительно влиять на подвижность и ориентацию молекул. Именно поэтому константы скоростей реакций адсорбированных радикалов могут сильно меняться в зависимости от характера поверхности $[46,47]$.

В чистой воде при медленном протекании процесса восстановления протонов воды образовавшийся атом водорода преимущественно реагирует не с таким же атомом, а с молекулой растворенного кислорода, концентрация которого много выше (табл. 3):

$$
\mathrm{H}^{\bullet}+\mathrm{O}_{2} \rightarrow \mathrm{HO}_{2}^{\bullet}
$$

При столкновении двух радикалов $\mathrm{HO}_{2}^{\bullet}$ образуются $\mathrm{H}_{2} \mathrm{O}_{2}$ и ${ }^{1} \mathrm{O}_{2}^{*}$ по реакции (4), но при нейтральных и щелочных $\mathrm{pH}$ водной среды $\mathrm{HO}_{2}^{\bullet}$, не успевший прореагировать с таким же, распадается с образованием протона и $\mathrm{O}_{2}^{-\bullet}\left(\mathrm{pK}_{\mathrm{a}} \sim 4.8\right)$ :

$$
\mathrm{HO}_{2}^{\bullet} \leftrightarrow \mathrm{H}^{+}+\mathrm{O}_{2}^{-\bullet}
$$

Освободившийся в этой реакции протон снова может вступать в реакции электронного переноса на поверхности электрода, а затем передавать электрон новой молекуле кислорода с образованием отрицательно заряженного иона $\mathrm{O}_{2}^{-\bullet}$. Так, католит может приобретать и накапливать электрический заряд. Этот процесс сильно зависит от свойств поверхности электрода и условий диффузии различных компонент раствора вблизи него. Поскольку $\mathrm{O}_{2}^{-\bullet}$ обладает значительным отрицательным потенциалом, при его накоплении и росте $\mathrm{pH}$ редокспотенциал среды уменьшается.

Вблизи анода происходит электрохимическое разложение молекул воды и образование ОН-радикала и других сильных окислителей. Поэтому при использовании католита и анолита можно достигать тех же целей, что и при добавлении перехватчиков разных типов радикалов при импульсном фотолизе.

Образование окислительных и восстановительных видов АФК сильно сказывается на спектрах комбинационного рассеяния (КР) воды. Так, в работе [104] показано, что КР католита и анолита заметно отличаются от спектров исходной воды. Авторы полагают, что в католите и анолите появляются электрические заряды разных знаков, обусловленные присутствием избыточных ионов, $\mathrm{OH}^{-}$и $\mathrm{H}^{+}$, однако без противоионов, вводимых в виде химических добавок при подкислении или подщелачивании среды. Поэтому возникают водные агрегаты вокруг избыточного электрического заряда радикалов с различными частотами колебаний в сетке водородных связей в католите и анолите. Эти процессы требуют тщательного изучения.

\section{Принципиальная микрогетерогенность водной среды}

В исследованиях воды и разбавленных водных сред присутствие в них растворенных атмосферных газов часто не принимается во внимание. Однако в настоящее время хорошо известно, что микропузырьки воздуха, всегда имеющиеся в воде, если не удалены специально, оказывают на нее заметное влияние. Так, после дегазации воды существенно меняются процессы формирования микроэмульсий [101], исчезает чувствительность к слабым магнитным и электромагнитным полям $[100,105]$ 
и изменяется характер релаксации водной среды после различных воздействий $[106,107]$. Микроскопические пузырьки являются зародышами кавитации, поэтому их число, размер, газовый состав и свойства поверхности сильно влияют на кавитационную прочность и сонолюминесценцию воды [55]. Содержание газов в воде сильно зависит от методов ее обработки, а нарушенное равновесие восстанавливается относительно медленно. Отрицательно заряженные ионы являются зародышами образования пузырьков в воде [108] и при малых размерах пузырьков препятствуют их схлопыванию [109]. Установлено, что невысокие концентрации растворенных газов стабилизируют локальную структуру жидкой воды с образованием так называемых клатратов. При этом для газов $\mathrm{Ar}, \mathrm{Kr}, \mathrm{N} 2$, и $\mathrm{O}_{2}$ наряду со стабилизацией структуры имеет место эффект развития зон упорядоченности структуры воды [110].

Различные режимы нагревания воды по-разному влияют на состояние пузырьков. Так, в работе [111] изложены результаты измерения ширины полосы протонного магнитного резонанса для аэрированной дистиллированной воды и таких же образцов воды, быстро охлажденной после нагрева до $90^{\circ} \mathrm{C}$ или после длительного кипячения. Установлено, что по сравнению с исходной аэрированной водой кратковременный нагрев до $90^{\circ} \mathrm{C}$ способствует увеличению упорядоченности воды, в то время как длительное кипячение уменьшает упорядоченность. В этих экспериментах производилось измерение содержания кислорода в различных модификациях воды. В равновесной воде при $20^{\circ} \mathrm{C}$ содержалось $9.05 \mathrm{mg} / 1$, после нагрева до $90^{\circ} \mathrm{C}$ и длительного кипячения с последующим охлаждением - 5.2 и $2-3 \mathrm{mg} / 1$ соответственно. Так как кратковременное нагревание должно в первую очередь удалять крупные пузырьки, радиус которых превышает критический, то можно полагать, что именно их удаление способствует большему упорядочиванию структуры. При длительном кипячении удаляются и более мелкие пузырьки, что, по-видимому, уменьшает структурированность воды. Из приведенных данных можно сделать вывод, что сильнее растущие в результате нагрева и удаляющиеся при кипении большие пузырьки отличны по своему газовому составу от малых. В частности, об этом свидетельствуют результаты работы Б. Емеца [112]. Показано, что повышение температуры дистиллированной воды всего на $4.5^{\circ} \mathrm{C}$ в результате освещения лампочкой накаливания $(30 \mathrm{~W}, 30 \mathrm{~min}$.) приводит к 45\% уменьшению содержания воздуха в пузырьках. В то же время концентрация растворенного кислорода, измеренная методом ЯМР по изменению времени протонной магнитной релаксации, уменьшается всего на $12 \%$. Можно полагать, что при нагревании воды диффузия молекул водяного пара преимущественно способствует росту и удалению крупных пузырьков, в то время как газообразный кислород сохраняется в мелких заряженных пузырьках и клатратоподобных полостях.
Присутствие заряженных газовых пузырьков в водных средах доказано непосредственными измерениями [113115], хотя это не общепризнано [116].

\section{Газовые гидраты в воде}

Известно, что многие промышленные процессы при положительных температурах и высоком давлении газа могут сопровождаться образованием газовых гидратов - образований, похожих на снег или рыхлый лед, которые могут приводить к закупорке трубопроводов и аппаратов. Молекулы газа размещаются в полостях кристаллической решетки из молекул воды и удерживаются в них силами Ван-дер-Ваальса. Эти полости имеют вид многогранников. Такие структуры хорошо известны для многих газов и легкокипящих жидкостей $\left(\mathrm{O}_{2}, \mathrm{~N}_{2}, \mathrm{Ar}, \mathrm{Xe}, \mathrm{Cl}_{2}, \mathrm{CH}_{4}, \mathrm{CHCl}_{3}\right.$ и др.) Ингибиторами образования газовых гидратов являются растворы солей, спирты, гликоли и другие соединения, связывающие воду. На возможность фазовых переходов в водных средах, содержащих атмосферные газы при высоких давлениях и низкой температуре, указывалось еще в работе Л. Полинга [117]. Известно, что повышение давления свыше атмосферного увеличивает растворимость воздуха в крови [118]. При подъеме водолазов из глубины быстрое уменьшение давления приводит к закупорке сосудов выделяющимися из крови пузырьками азота - кессонной болезни. Попытки устранить это явление привели к открытию кислородного наркоза. Оказалось, что при парциальном давлении кислорода выше $1.7 \mathrm{~atm}$ (соответствует глубине погружения ныряльщика без снаряжения на глубину более $50 \mathrm{~m}$ ) наступает явление эйфории, обусловленное наркотическим действием атмосферного кислорода, растворяющегося в крови при повышенном давлении. В дальнейшем оказалось, что тяжелые инертные газы обладают наркотическим действием при гораздо меньших парциальных давлениях. Критические давления для криптона и ксенона составляют 0.50 и $0.22 \mathrm{~atm}$ соответственно. Анестезиологи считают смесь $20 \%$ кислорода и $80 \%$ ксенона идеальным усыпляющим средством при хирургических вмешательствах, поскольку оно полностью обратимо, безынерционно и нетоксично. Оказалось, что даже водород и гелий при высоких давлениях оказывают наркотическое действие [118].

Полинг установил, что парциальное давление, необходимое для достижения определенной степени наркоза, пропорционально давлению кристаллизации гидрата применяемого анестетика (параметрам межмолекулярного взаимодействия газ-вода) и предположил, что явление наркоза связано с изменением водного окружения биологически активных веществ, растворенных во внутричерепной жидкости. Полинговская теория анестезии, уточненная современными опытами и расчетами, предполагает, что растворенные газы, меняющие структуру воды вблизи биологической мембраны, приводят к фазовому переходу в воде, нарушающему ее структуру. Это 
вызывает процесс расслоения, т. е. выпадение из водного раствора каких-то биологически важных компонентов, что приводит к остановке процессов с их участием. В результате этого нарушается химическая передача определенных сигналов, что должно восприниматься как потеря чувствительности, т.е. наркоз. Поскольку вода составляет основную часть биологических тканей, то изменение ее характеристик может являться управляющим фактором для протекающих в ней процессов. Интересно, что рентгенограммы сжиженных газов аргона (одноатомного) и кислорода (двухатомного) оказались практически идентичными. Оказалось, что и в водном окружении они имеют очень близкие значения парциального давления, приводящего к наркозу (1.6-1.7 atm). По-видимому, оба эти газа, несмотря на различия в молекулярной структуре, создают близкое водное окружение. В последние годы появились экспериментальные доказательства значительного влияния аргона на хемилюминесцентные процессы с участием АФК в водной среде [119].

\section{Растворы с нижней критической температурой расслоения (НKT)}

Растворы с НКТ, к которым, в частности, относятся ди- и триметилпиридиновые соединения, изучались экспериментально и теоретически [120]. Подобные структуры характерны для многих лекарственных веществ, витаминов и других биологически активных соединений (образующих, в частности, класс пиридилрадикалов, активно взаимодействующих с кислородом и всеми другими парамагнитными частицами; важный пример таких соединений - NAD $(\mathrm{P}) \mathrm{H})$. Такие растворы расслаиваются на две фазы, обогащенные каждая своим компонентом, не при охлаждении, как обычно, а при нагревании. Для фазовой диаграммы таких растворов характерно наличие минимальной температуры расслоения, флуктуации концентрации в которой аномально растут, и наблюдается переход второго рода с нижней критической точкой. Практически все растворы с НКТ составлены из молекул, способных образовывать водородные связи $\mathrm{H}-\mathrm{O}, \mathrm{H}-\mathrm{F}, \mathrm{H}-\mathrm{N}$ и живущие конечное время ассоциаты. Утверждается, что такие системы проявляют целый ряд акустических, магнитных и оптических эффектов [121,122]. Критические условия задает конкуренция процессов образования в растворе водородных связей двух, по-разному зависящих от температуры, типов: между молекулами растворителя и между молекулами растворителя и растворенного вещества. Такие системы нелинейны, поэтому флуктуации внешних источников энергии могут качественно изменять их динамику. Накоплено достаточно много экспериментальных данных, свидетельствующих о том, что и биологические системы могут менять режимы своего функционирования при действии энергетически слабых (дотепловых) факторов.
В этом отношении они очень напоминают растворы с HКT.

Экспериментальное изучение воды и водных растворов лазерными методами позволило выявить ряд особенностей, связанных, по-видимому, с коллективными взаимодействиями в сетке водородных связей $[120$ 123]. Так, методом четырехфотонной поляризационной спектроскопии в диапазоне $10-100 \mathrm{~cm}^{-1}$ обнаружена структура, связанная, как полагают [123], с коллективными модами воды. Около $6 \mathrm{~cm}^{-1}$ обнаружена полоca, которую связывают с колебаниями протона вдоль водородной связи. В крыле релеевской линии обнаруживается четко выделенный пик $1.4 \mathrm{~cm}^{-1}(\sim 7 \mathrm{~mm})$, который специально поставленными экспериментами связали с упорядочением структуры воды под действием миллиметрового излучения. В большом числе работ по низкоинтенсивным воздействиям на воду делается вывод о влиянии содержания газов на ее свойства (например, [124]).

В настоящее время очень широко используются методики создания в водных средах пузырьков разных размеров и газового состава, от ультратонких (наноразмерных) до крупных, и исследуются особенности их поведения $[115,116]$. Раздавливанию малых пузырьков препятствует электрический заряд, который может создаваться не только ионами химических примесей, но и появляться в процессе разложения воды в присутствии атмосферных газов. Так, после кратковременного облучения чистой воды ультрафиолетом, а также после электролиза в электролизере с разными ячейками для электродов или после встряхивания в воде в течение долгого времени постепенно растет электропроводность [125]. На рис. 7 показана диаграмма изменений электропроводности в течение двух суток исходной воды и такой же воды после 15-кратного разведения в 100 раз водой. Также приведены данные для аналогичных образцов после облучения ультрафиолетом (за 100\% принято значение электропроводности исходной воды до облучения.) Для сравнения с водой на этой же диаграмме приведены соответствующие данные для 15-кратного разведения в 100 раз исходно 0.2 М-раствора хлористого натрия. Можно видеть, что исходно проводимость всех образцов имеет близкие значения, но со временем после разных воздействий на систему АФК динамика изменений проводимости во всех системах различная.

О сложном взаимодействии растворенных газов и структуры водного окружения свидетельствуют процессы, наблюдаемые при замораживании воды. Известно, что движение фронта кристаллизации сопровождается появлением значительных электрических потенциалов на фазовых границах лед-вода [126]. Фазовая граница оказывается морфологически неустойчивой по отношению к образованию выступов и разрастанию их в боковые ветви, которые формируют дендритную поликристаллическую структуру. Неравномерное движение морфологически неустойчивой и электрически активной фазовой границы может сопровождаться импульсным 


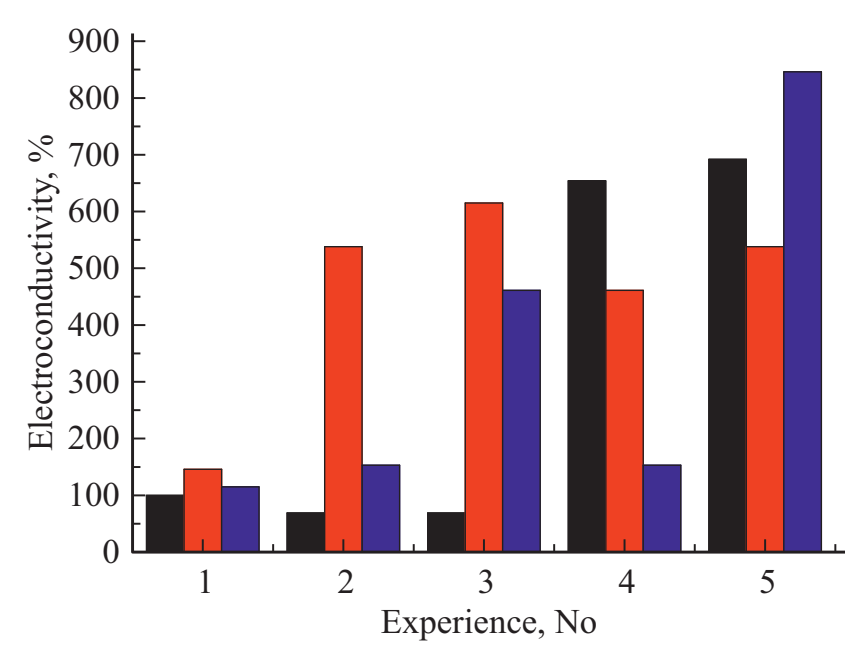

Рис. 7. Электропроводность очищенной воды (черный цвет), $15 \mathrm{C}-\mathrm{H}_{2} \mathrm{O}$ (красный цвет) и $15 \mathrm{C}-\mathrm{NaCl}$ (синий цвет): 1 исходно, 2 - через сутки, 3 - через двое суток; 4 и 5 такие же образцы через сутки и двое после 2 min облучения ультрафиолетом соответственно. Электропроводность исходной очищенной воды принята за 100\% [125].

излучением электромагнитных и акустических волн (радиоизлучение, „треск“ льда, криолюминесценция) [127]. При замораживании воды движение фронта кристаллизации вытесняет растворенные газы из пустот тетраэдрической решетки льда. Газы собираются в пузырьки и в зависимости от условий замораживания либо огибаются фронтом кристаллизации, либо выдавливаются из системы. В результате этого замораживание воды приводит к ее частичной дегазации. В жидкой воде, сохраняющей ближний порядок тетраэдрического расположения, упаковка элементарной ячейки более плотная, чем во льду, поэтому можно думать, что условия межмолекулярного взаимодействия вода-газ еще в меньшей степени, чем во льду, не способствуют растворению газа в виде свободных молекул, диффундирующих между молекулами воды в сетке водородных связей.

Все вышесказанное позволяет предположить, что молекулы растворенных в воде газов ассоциированы в клатратоподобных полостях или в паровоздушных пузырьках при всех температурах. В такой элементарной ,ячейке“ , окружающей клатрат или воздушный пузырек, плотность заряда и дипольного момента, усредненная по времени и пространству, равна нулю. Межмолекулярные взаимодействия в ,ячейке“, а также взаимодействия между соседними ячейками определяются силами Вандер-Ваальса. Силы Ван-дер-Ваальса связаны с существованием у атомов или макроскопических тел флуктуационных плотностей заряда и тока и их взаимодействием через длинноволновое флуктуационное электромагнитное поле [128].

Известно, что для двух атомов в основном состоянии флуктуации носят квантовый характер, а сила взаимодействия между неполярными атомами и молекулами на больших расстояниях выражается формулой Лондона. Лондон назвал это взаимодействие дисперсионным, поскольку оно выражается через поляризуемости атомов, фигурирующие также и в теории дисперсии.

В простейшем случае для двух атомов, для каждого из которых существен только один переход с частотами $\omega_{1}$ и $\omega_{2}$, в пренебрежении запаздыванием и затуханием электромагнитного сигнала энергия взаимодействия имеет следующий вид:

$$
U(R)=-\frac{3 \hbar \omega_{1} \omega_{2}}{2\left(\omega_{1}+\omega_{2}\right)} \frac{\alpha_{1}(0) \alpha_{2}(0)}{R^{6}},
$$

где $\alpha_{1}(0)$ и $\alpha_{2}(0)-$ поляризуемости атомов при $T=0$. Эта энергия представляет собой изменение за счет диполь-дипольного взаимодействия энергии нулевых колебаний электрического поля, создаваемого нулевыми колебаниями дипольных моментов атомов. Это соотношение справедливо и для двух малых изотропных частиц конденсированной фазы, когда можно пренебречь запаздыванием и затуханием электромагнитного сигнала, а также ограничиться диполь-дипольным приближением. Для атомов благородных газов, имеющих завершенную электронную оболочку, силы межатомного взаимодействия определяются только дисперсионными взаимодействиями Ван-дер-Ваальса. Эти силы определяют особенности поведения благородных газов в воде. Они не зависят от температуры. Для молекул других газов наряду с дисперсионными имеют место и другие типы взаимодействий.

Изучено включение в клатратные полости шарообразной молекулы фуллерена (радиус около $0.5 \mathrm{~nm}$ ) [129132]. Она хорошо вписывается в естественную структуру клатрата и стабилизирует его. Обычно поверхность молекулы фуллерена в воде приобретает отрицательный заряд, так как эта молекула обладает значительным электроно-акцепторным потенциалом и поляризует молекулы поверхностного слоя воды. Это облегчает диссоциацию протонов воды и способствует разделению зарядов вблизи поверхности полости. Такой водный кластер состоит из относительно жестко связанной воды вблизи поверхности фуллерена и менее упорядоченных водных слоев, простирающихся на весьма значительное расстояние от центра кластера. По оценкам светорассеяния радиус всего упорядоченного слоя воды вокруг молекулы фуллерена составляет 23-80 nm [129]. Полагают, что промотирование упорядоченной структуры воды является следствием кооперативности водородных связей. Этим объясняется и увеличение растворимости при переходе от легких газов $\left(\mathrm{H}_{2}, \mathrm{He}\right)$ к $\mathrm{Ar}, \mathrm{O}_{2}$ и другим газам. Известен аутосинергический эффект растворимости, т.е. усиление структурирующего воздействия на воду молекул растворенного газа в присутствии других идентичных молекул [110].

В полярных жидкостях, когда молекула обладает постоянным дипольным моментом $d$, и в нуль обращается 
значение среднего дипольного момента после статистического усреднения по всем возможным ориентациям оси диполя, сила ван-дер-ваальсова взаимодействия между двумя диполями имеет вид

$$
\begin{aligned}
F= & -\frac{d_{1}^{2} d_{2}^{2}}{3 T R^{6}}-\frac{\alpha_{e 1}(0) d_{2}^{2}+\alpha_{e 2}(0) d_{1}^{2}}{R^{6}} \\
& -\frac{3 T \alpha_{e 1}(0) \alpha_{e 2}(0)}{R^{6}} .
\end{aligned}
$$

Первое слагаемое описывает классическое ориентационное взаимодействие дипольных молекул с дипольными моментами $d_{1}$ и $d_{2}$, второе слагаемое отвечает индукционному взаимодействию Дебая-Фалькенхагена, а третье можно рассматривать как классический предел дисперсионного взаимодействия. Если зависимостью поляризуемостей от температуры можно пренебречь, то дисперсионное слагаемое обусловлено чисто энтропийным вкладом в свободную энергию [128].

В воде, как и других полярных жидкостях, в эффективную поляризуемость среды существен вклад ориентационных взаимодействий молекул. Подсчитано, что в воде (без учета полостей и пузырьков) вклад дисперсионного взаимодействия составляет лишь $24 \%$ от полного вандер-ваальсова взаимодействия, а вклад ориентационных взаимодействий - примерно 69\% [128]. Однако по расчетам Цунделя [133] дисперсионные взаимодействия осциллирующих протонов в симметричных комплексах $\mathrm{O}-\mathrm{H} \cdots \mathrm{O}$, реализуемых в водородных связях воды, обладают гигантской поляризуемостью. Зацепина полагает [134], что именно они дают основной вклад в энергию коллективных протонных осцилляций молекул воды, связанных водородными связями. Ею сделан вывод о том, что неэквивалентность протона и дейтрона в протиевой и тяжелой воде обусловлена тем, что в $\mathrm{D}_{2} \mathrm{O}$ сильнее локальное взаимодействие и слабее дисперсионное. Эти и другие особенности объемной и приповерхностной воды привлекают пристальное внимание и изучаются современными лазерными методами $[135,136]$.

Эффект возникновения долговременных колебаний интенсивности хемилюминесценции воды спустя 4-5h после пяти минут лазерного облучения воды в полосе поглощения кислорода [137], названный „светокислородным эффектом“, трудно объяснить прямым окислением гидроксильной группы молекулы чистой воды синглетным кислородом с образованием ОН-радикала, поскольку это энергетически не выгодно. Поэтому при нейтральных значениях $\mathrm{pH}$ должна быстро протекать обратная реакция [138-140]. Однако было обнаружено, что антитела способны образовывать перекись водорода из синглетного кислорода $[94,95,141]$. Полагают, что это связано с непосредственным взаимодействием молекул ${ }^{1} \mathrm{O}_{2}^{*}$ и воды с образованием и последующим распадом водно-кислородных комплексов. Поскольку время жизни ${ }^{1} \mathrm{O}_{2}^{*}$ в тяжелой воде много больше, чем в протиевой, и сильно зависит от полярности среды, была сделана попытка изучить реакции тушения ${ }^{1} \mathrm{O}_{2}^{*}$ в обращенных микроэмульсиях [142] с разным содержанием воды. Был получен результат, что время жизни ${ }^{1} \mathrm{O}_{2}^{*}$ в упорядоченных водных структурах больше, чем в хаотических. Хотя этот результат по признанию авторов требует дальнейшего исследования, можно полагать, что между скоростью дезактивации синглетного кислорода и интенсивностью колебаний в системе водородных связей есть взаимозависимость. Можно предположить, что энергия возбуждения кислорода запасается в колебаниях протонов в сетке водородных связей между молекулами воды. В экспериментах с возбуждением колебаний интенсивности хемилюминесценции лазерным облучением [51] за латентное время (часы) колебания отдельных связей взаимодействуют между собой и постепенно упорядочиваются, в результате чего избыточная энергия сосредоточивается на определенных водородных связях, контактирующих с радикалами АФК и молекулами перекиси, адсорбированными на границах раздела фаз. Вследствие этого происходят процессы периодического накопления и распада пероксидов, тесно взаимодействующих с окружающей водной матрицей. Накопление и разложение $\mathrm{H}_{2} \mathrm{O}_{2}$ сопровождается поглощением и выделением протонов соответственно. В результате этих процессов возникают колебания окислительно-восстановительного потенциала, $\mathrm{pH}$ и оптических излучений водной среды. Вспышки света, сопровождающие лавинообразное разложение накопленных пероксидов, регистрируются люминесцентными и хемилюминесцентными методами. Спектры флуоресценции таких вспышек отражают лавинообразное появление спектров АФК, среди которых наиболее ярко проявлены спектры разлагающейся $\mathrm{H}_{2} \mathrm{O}_{2}$ $(\sim 510-530 \mathrm{~nm})$ и ${ }^{1} \mathrm{O}_{2}^{*}$ в различных энергетических состояниях (табл. 2 и рис. 2,3 ). Эти спектры близки к спектрам излучений, сопровождающих разложение $\mathrm{H}_{2} \mathrm{O}_{2}$ при катализе ионами железа в реакции Фентона [45] (рис. 8). Поскольку полосы излучений такой вспышки совпадают со спектрами излучений ${ }^{1} \mathrm{O}_{2}^{*}$ в газовой фазе, а во время такой вспышки резко падает интенсивность релеевского светорассеяния, можно полагать, что вспышка сопровождается разрушением паровоздушных пузырьков, контактирующих с перекисью.

В этой связи интересны результаты работы по передаче возбуждения, инициированного лазерным импульсом, между молекулами в протиевой и дейтерированной воде $[143,144]$. Показано, что в протиевой воде возбуждение распространяется много эффективнее, чем в дейтериевой. По-видимому, это и приводит к быстрой дезактивации синглетного кислорода в обычной воде. Аналогичные исследования эффективности переноса возбуждения по системе водородных связей между молекулами воды в условиях повышенной генерации ${ }^{1} \mathrm{O}_{2}^{*}$ (как и других видов АФК) могли бы прояснить механизмы взаимодействия АФК с водным окружением и границами раздела фаз. 

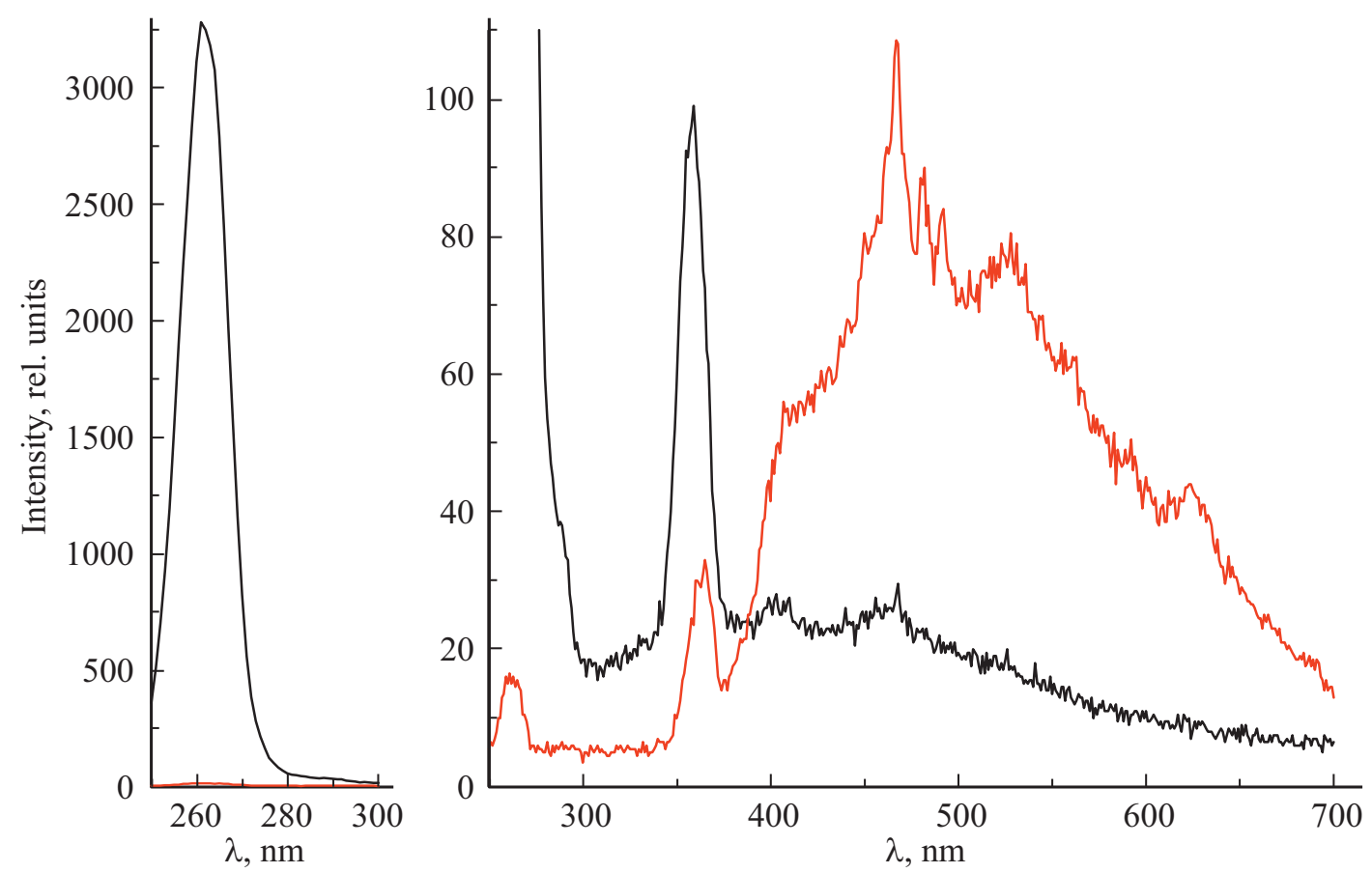

Рис. 8. Спектры релеевского светорассеяния (слева) и флуоресценции (справа) при $\lambda_{\text {ех }}=260 \mathrm{~nm}$ сульфата железа (концентрация $1 \mu \mathrm{m}$ - черный цвет) исходно и после добавления перекиси водорода (ОСЧ $0.015 \%$ по объему - красный цвет). При добавлении $\mathrm{H}_{2} \mathrm{O}_{2}$ спектр светорассеяния пропадает почти полностью [50].

\section{Вода исключенной зоны}

Поллак показал, что пограничная вода, гидратирующая гидрофильную поверхность полимера Нафиона, настолько отличается по своим свойствам от „объемной“, что ее можно считать жидкокристаллической [145]. Толщина слоя такой воды у гидрофильных поверхностей может достигать сотен микрон. Она отличается от объемной воды по вязкости, плотности, температуре замерзания, диэлектрическим свойствам. Множество веществ, хорошо растворимых в обычной воде, в этой воде не растворяются, и поэтому Поллак назвал воду, прилегающую к гидрофильным поверхностям, exclusion zone water (EZ-water или вода зоны исключения). Три свойства EZ-воды указывают, что она может играть важную роль в биоэнергетике: во-первых, EZ-вода заряжена отрицательно относительно контактирующей с ней объемной воды (ее потенциал достигает $-150 \mathrm{mV})$, вовторых, в ней обнаружен пик поглощения УФ света при $270 \mathrm{~nm}$, в-третьих, толщина слоя EZ-воды увеличивается при освещении видимым светом и особенно при поглощении ИК излучения.

Полагают, что электроны в EZ-воде возбуждены сильнее, чем в обычной воде, т.е. она может выступать в роли восстановителя [96]. Акцептором энергии и электронов служит растворенный в воде кислород. Электрогенные свойства EZ-воды, определяющие ее потенциал относительно объемной воды, зависят от свойств той поверхности, что формирует EZ-воду. Чем выше плотность фиксированного отрицательного заряда на смачиваемой поверхности, чем больше площадь этой поверхности, тем больше электронная емкость формируемой этой поверхностью EZ-воды. В EZ-зоне образование $\mathrm{H}_{2} \mathrm{O}_{2}$ при освещении светом $1274 \mathrm{~nm}$ (в полосе поглощения кислорода) идет слабее, чем в объемной воде, латентный период длиннее, а осцилляции хемилюминесценции имеют одну частоту вместо трех частот в объемной воде [146].

Из свойств EZ-воды следует, что поскольку плотность электрического заряда в малых заряженных пузырьках должна быть высокой во избежание их раздавливания, то вблизи таких границ раздела фаз вода подобна воде исключенной зоны. Физико-химические механизмы образования EZ-воды еще требуют изучения, поскольку возможны эффекты изменения свойств поверхности самого Нафиона при набухании. Однако сильное изменение свойств приповерхностной воды в обращенных микроэмульсионных системах указывает на возможность подобного явления и для поверхности Нафиона. Воейков полагает [96], что любая водная система в первом приближении может рассматриваться как двухфазная, одна из фаз которой представлена организованной водой, обладающей восстановительными свойствами, а другая менее организованной объемной водой. В той и другой системе присутствуют активные соединения $-\mathrm{H}_{2} \mathrm{O}_{2}$, кислород и другие атмосферные газы. В результате в такой системе возникает сеть взаимно поддерживающих друг друга реакций, а энергетический выход большинства из них обеспечивает генерацию энергии электронного возбуждения. 


\section{Когерентные домены воды}

Теория воды, основанная на законах квантовой электродинамики, выдвинутая впервые в 1988 г. Дель Джудиче, Препарата и Витиелло [147], в дальнейшем развита Эмилио Дель Джудиче [148]. Из квантовой электродинамики следует, что жидкая вода представляет собой совокупность когерентных доменов, в каждом из которых осцилляции протонов молекул воды взаимозависимы. В нормальной воде отдельные когерентные домены не зависят друг от друга, поэтому ориентированы хаотически. Размер каждого когерентного домена соответствует длине волны квантового перехода молекулы воды из основного в возбужденное состояние. Из квантово-механических расчетов Дель Джудиче следует, что различие в энергии основного и первого возбужденного состояний когерентного домена воды составляет $12.06 \mathrm{eV}$, что соответствует длине волны фотона мягкого рентгеновского излучения $100 \mathrm{~nm}$. Размер когерентного домена воды (при комнатной температуре) около $0.1 \mu \mathrm{m}$. Это соответствует длине электро-магнитной волны $\sim 1 \mu \mathrm{m}$ (по оценкам длина волны излучения на порядок больше области структуры, колеблющейся в одной фазе). Согласно Дель Джудиче, особенностью воды, отличающей ее от всех других жидкостей, является то, что энергия возбужденного состояния когерентного домена очень близка энергии ионизации молекулы воды, составляющей $12.6 \mathrm{eV}$. Область синхронных колебаний протонов разных доменов может увеличиваться в результате различных воздействий. Синхронизация различных доменов при внешних воздействиях может происходить, если есть отвод избыточной энергии, поскольку общая энергия синхронно колеблющихся доменов уменьшается [149].

Близкие идеи развивала Г. Зацепина, называя когерентный домен Дель Джудиче областью синхронных колебаний протонов [134]. По ее расчетам размер кластера воды, в котором колебания протонов синхронны, составляет до $10 \mu \mathrm{m}$ и соответствует длине волны либрационных межмолекулярных колебаний.

Подводя итог, можно заключить, что коллективные осцилляции протонов молекул воды, связанных водородными связями, играют существенную роль. Возможно, что и когерентные домены, и вода исключенной зоны оказывают влияние на состояние воды. Однако несомненно должны учитываться роли паровоздушных пузырьков и АФК при анализе этих моделей. Можно предложить следующее дополнение к модели когерентного домена Дель Джудичи.

Возбуждение и разложение молекул воды под влиянием радиационного поля Земли может приводить к тому, что процесс накопления зарядов в когерентном домене из-за стабилизации электрически заряженных молекул супероксида на поверхности газовых пузырьков будет проходить постоянно. Отрицательно заряженная поверхность пузырька окружается положительно заряженным диффузным слоем ионов гидроксония. Подвиж- ность отрицательного электрического заряда пузырьков и положительного заряда окружающих пузырек ионов гидроксония существенно различается, поэтому при слабых акустических воздействиях, переливаниях и встряхиваниях воды центры положительного и отрицательного зарядов разделяются, появляются осциллирующие объемные „диполи“. В воде масштабы времени, характеризующие различные релаксационные процессы (электрические, упругие, тепловые), существенно различаются, а возбуждения эффективно мигрируют за счет диполь-дипольного взаимодействия ближайших протонов молекул воды. Это может быть причиной экспериментально наблюдаемых долговременных осцилляций параметров светорассеяния, флуоресценции и хемилюминесценции водной среды и растворенных в ней газов после прекращения воздействия. При встряхиваниях и переливаниях разные диполи взаимодействуют и взаимно упорядочиваются, поэтому после прекращения воздействия в такой структуре продолжается процесс взаимной синхронизации. В результате этого постепенно затухают высокочастотные колебания, а низкочастотные могут усиливаться. Это приводит к появлению различных релаксационных процессов, в том числе периодического или квазипериодического характера [150]. Период этих колебаний составляет минуты и часы, и, однажды возникнув, колебания могут продолжаться в течение десятков часов и более.

Аналогичный сценарий могут реализовать и колебания ансамбля ядерных спинов протонов вокруг каждого осциллирующего пузырька. Они должны определяться колебаниями локальных электромагнитных полей и, в свою очередь, влиять на протекание реакций дисмутации радикалов на поверхностях. Возможно, именно этот механизм отвечает за медленное установление равновесия при изменении содержания орто- и пара-молекул воды [151].

Эти факты позволяют рассматривать АФК и обьем водной матрицы как единую сложную динамическую систему, способную накапливать энергию в колебаниях сетки водородных связей, огибающей заряженные газовые пузырьки. Размеры, электрический заряд и взаимодействие с окружающими протонами водной среды таких пузырьков определяет динамику всего водного домена. Опыт показывает, что есть некие критические условия содержания АФК для появления пространственной и временной упорядоченности. Так, введение в водную среду небольших количеств перекиси водорода и гидрокарбоната натрия приводит к появлению хемилюминесцентной системы, способной излучать энергию в течение многих месяцев, причем в условиях, исключающих обмен веществом (кислородом, продуктами реакции) со средой и к тому же в полной темноте. Интенсивность излучения колеблется с суточной периодичностью и является чувствительной к некоторым геофизическим процессам низкой интенсивности [152,153].

Эти эксперименты дают основание вспомнить и наблюдения резкого увеличения времени жизни гете- 
ротрофных бактерий, разводимых в водной среде с ограниченным добавлением субстрата [154,155]. Можно полагать, что отмеченное в работе приобретение чувствительности к геофизическим факторам в условиях субстратного голодания связано с более благоприятным протеканием реакций с участием АФК.

Интересно отметить, что изучение суспензий митохондрий высокочувствительными методами когерентной интерферометрической микроскопии [156] позволило установить, что повышение уровня АФК в системе вызывает увеличение области „кооперативного“, скоррелированного между собой состояния митохондрий. Указывается, что увеличение содержания АФК в суспензии митохондрий приводит к взаимной ориентации этих органелл.

Экспериментальное изучение механизмов процессов с участием АФК представляет собой весьма трудную задачу в связи с их малой концентрацией, сложными взаимодействиями между собой, с водой и всегда присутствующими в воде атмосферными газами, примесями ионов металлов и органических соединений, а также изза чувствительности этих процессов к наличию границ раздела фаз, радиационному фону и многим другим факторам. Однако сама возможность влияния на живые организмы геофизических факторов управлением процессами с участием АФК через состояние водных систем требует всестороннего изучения.

\section{Список литературы}

[1] Khan A.U., Wilson T. // Chem. Biol. 1995. V. 2 P. 437-445.

[2] Hayyan M., Hashim M.A., AlNashef I.M. // Chem. Rev. 2016. V. 116. P. 3029-3085. doi.org/10.1021/acs.chemrev.5b00407

[3] Dickinson B.C., Chang C.J. // Nature Chemical Biology. 2011. V. 7. N 8. P. 504-511. doi 10.1038/nchembio.607

[4] Patel R., Rinker L., Peng J., Chilian W.M. Reactive Oxygen Species (ROS) in Living Cells. 2018. doi 10.5772/intechopen.71547

[5] Scherz-Shouval R., Elazar Z. // Trends in Cell Biol. 2007. V. 17. N 9. P. 422-427. doi 10.1016/j.tcb.2007.07.009

[6] Massaad C.A., Klann E. // Antiox. Redox Signal. 2011. V. 14. N 10. P. 2013-2054. doi 10.1089/ars.2010.3208

[7] Collin F. // Int. J. Mol. Sci. 2019. V. 20. N 10. P. 2407. doi 10.3390/ijms20102407

[8] Фридович И. // Свободные радикалы в биологии / Под ред. Прайор У. М.: Мир, 1979. С. 272-308.

[9] Krumova K., Cosa G. // Overview of Reactive Oxygen Species: Appl. in Biosci. Nanosci. 2016. V. 1. P. 1-21. doi 10.1039/9781782622208-00001 eISBN: 978-1-78262220-8

[10] Гольштейн Н.И., Гольштейн Р.Н. // Природа. 2009. № 4. C. $28-35$.

[11] Свободные радикалы в биологии / Под ред. Прайор У.М.: Мир, 1979.

[12] Beckhauser T.F., Francis-Oliveira J., De Pasquale R. //J. Exp. Neurosci. 2016. V. 10. P. 23-48.

[13] Кузин А.М. // Биофизика. 2000. Т. 45. № 1. С. 144-151.
[14] Pozdnyakov I.P., Salomatova V.A., Parkhats M.V., Dzhagarov B.M., Bazhin N.M. // Mendeleev Commun. 2017. V. 27. P. 399-401. doi 10.1016/j.mencom.2017.07.028

[15] Perminova I.V., Grechichsheva N.Yu., Kovalevskii D.V., Petrosyan V.S., Matorin D.N. // Environ. Sci. Technol. 2001. V. 35. P. 3841-3848.

[16] Semyachkina-Glushkovskaya O.V., Sokolovski S.G., Goltsov A., Gekaluyk A.S., Saranceva E.I., Bragina O.A., Tuchin V.V., Rafailov E.U. // Progr. Quant. Electron. 2017. V. 55. P. 112-128.

[17] Novo E., Parola M. // Fibrogen. Tissue Repair. 2008. V. 1. P. 31-58. doi 10.1186/1755-1536-1-5

[18] Murphy M.P., Holmgren A., Larsson N.-G., Halliwell B., Chang C.J., Kalyanaraman B., Rhee S.G., Thornalley P.J., Partridge L., Gems D., Nyström T., Belousov V., Schumacker P.T., Winterbourn C.C. // Cell Metab. 2011. V. 13. P. 361-366. doi 10.1016/j.cmet.2011.03.010

[19] Burhans W., Heintz N. // Free Radic. Biol. Med. 2009. V. 47. P. $1282-1294$.

[20] Свободные радикалы, антиоксиданты и болезни человека. / Труды конф. Смоленск. 19-22 сентября. 2001.

[21] Afanas'ev I. // Aging and Disease. 2011. V. 2. P. 219-230.

[22] Фуm X. // Свободные радикалы в биологии. / Под ред. Прайор У. М.: Мир, 1979. С. 96-143.

[23] Владимиров Ю.А. // Биофизика. 1987. Т. 32. № 5. C. $830-844$.

[24] Подколзин А.А., Мегреладзе А.Г., Донщов В.И., Арутюнов С.Д., Мрикаева О.М., Жукова Е.А. // Профилактика старения. 2000. № 3. С. 1. https://medi.ru/info/8441/

[25] Обухова Л.К., Эмануэль Н.М. // Усп. химии. 1983. Т. 52. № 3. C. $353-372$.

[26] Скулачев В.П., Скулачев М.В., Фенюк Б.А. Жизнь без старости. М., 2014. https://coollib.com/b/4

[27] Воейков В.Л. // Автореф. докт. дис. М., 2003.

[28] Voeikov V.L. // Rivista di Biologia. 2001. V. 94. P. 193-214.

[29] Саакян И.Р., Гогвадзе В.Г., Сирота Т.В., Ставровская И.Г., Кондрашова М.Н. // Биофизика. 1998. Т. 43. № 4. С. 580-587.

[30] Ставровская И.Г., Сирота Т.В., Саакян И.Р., Кондрашова М.Н. // Биофизика. 1998. Т. 43. № 5. С. 766-771.

[31] Кузин А.М., Суркенова Г.Н., Заччкина С.И., Аптикаева Г.Ф., Ахмадиева А.Х., Розанова О.М., Клоков Д.Ю. // ДАН. 1998. Т. 358. № 1. С. 122-124.

[32] Воейков В.Л. // Благотворная роль активных форм кислорода. 2001. Сб. № 24-1. Научно-исследовательский центр „ИКАР“

[33] Дубинина E.E. // Вопр. Мед. Хим. 2001. Т. 6. С. 561-581.

[34] Турпаев К.T. // Биохимия. 2002. Т. 67. № 3. С. 339-352.

[35] Гривенникова В.Г., Виноградов А.Д. // Усп. биохимии. 2013. T. 53. C. $245-296$.

[36] Kindzelskii A.L., Zhou M.J., Haugland R.P., Boxer L.A., Petty H.R. // Biophys. J. 1998. V. 74. P. 90-97.

[37] Adachi Y. // J. Immunol. 1999. V. 163. P. 4367-4374.

[38] Воейков В.Л., Новиков К.Н., Виленская Н.Д., Буларгина Ю.С., Химич М.В. // Съезд биофизиков России. Симпозиум YII: Биофизика мембран. М., 1999. Т. 2. С. 657-658.

[39] Guzik T.J., Korbut R., Adamek-Guzik T. // J. Physiol. Pharmacol. 2003. V. 54. P. 469-487.

[40] Drapier J.-C., Bouton C., Oliveira L. // Nitric Oxide. 2000. P. 315-342.

[41] Wang P.G., Xian M., Tang X. // Chem. Rev. 2002. V. 102. P. 1091-1134. 
[42] Коган А.Х., Грачев С.В., Елисеева С.В. // ДАН. 1998. T. 362. № 5. C. 705-708.

[43] Medinas D.B., Cerchiaro G., Trindade D.F., Augusto $O$. // IUBMP Life. 2007. V. 59. P. 255-262. https://doi.org/10.1080/15216540701230511

[44] Denicola M.A., Freeman B.A., Trujillo M., Radi M.R. // Arch. Biochem. Bioph. 1996. V. 333. P. 49-58.

[45] Zhang H., Joseph J., Gurney M., Becker D., Kalyanaraman B. // J. Biol. Chem. 2002. V. 277. P. 1013-1020.

[46] Багрянская Е.Г., Сагдеев Р.3. // Успехи химии. 2000. Т. 69. № 11. C. 1009-1031.

[47] Лотник С.В., Хамидуллина Л.А., Казаков В.П. // ДАН. 1999. T. 366. № 4. C. 493-496.

[48] Tretter L., Adam-Vizi V. // J. Neurosci. 2004. V. 24. P. 7771-7778.

[49] Болдырев А.А., Куклей М.Л. // Нейрохимия. 1996. Т. 13. № 4. C. $271-278$.

[50] Belovolova L.V., Glushkov M.V., Vinogradov E.A., Babintsev V.A., Golovanov V.I. // Phys. Wave Phenomen. 2009. V. 17. P. $21-31$.

[51] Gudkov S.V., Bruskov V.I., Astashev M.E., Chernikov A.V., Yaguzhinsky L.S., Zakharov S.D. // J. Chem. Phys. B. 2011. V. 115. P. 7693-7698.

[52] Воейков В.Л., Химич М.В. // Биофизика. 2002. Т. 47. № 1. C. $27-30$.

[53] Шарипов Г.Л., Тухбатуллин А.А., Абдрахманов А.М., Мубтахутдинов М.P. // Вестн. Башкирского универ. 2011. T. 16. № 3. C. 658-661.

[54] Ikeda S., Takata T., Komoda M., Hara M., Kondo J.N., Domen K., Tanaka A., Hosono H., Kawazoe H. // Phys. Chem. Chem. Phys. 1999. V. 1. P. 4485-4491.

[55] Маргулис М.A. Звукохимические реакции и сонолюминесценция. М.: Химия, 1986.

[56] Домрачев Г.А., Родыгин Ю.Л., Селивановский Д.А. // Журн. физ. хим. 1992. Т. 66. № 3. С. 851-855.

[57] Вакс В.Л., Домрачев Г.А., Родыгин Ю.Л., Селивановский Д.А., Спивак Е.И. // Изв. вузов. Радиофизика. 1994. T. 37. № 1. С. 149-154.

[58] Почелуева М.М., Пустовидко А.В., Евтодиенко Ю.В., Храмов Р.Н., Чайлахян Л.М. // ДАН. 1998. Т. 359. № 3. C. 415-418.

[59] Гурвич А.Г., Гурвич Л.Д. Митогенетическое излучение, физико-химические основы и приложения в биологии и медицине. М.: Медгиз, 1945. 283 с.

[60] Тарусов Б.Н., Иванов И.И., Петрусевич Ю.М. Сверхслабое свечение биологических систем. М.: Изд-во МГУ, 1967.

[61] Popp F.-A. // Biophotonics. M.: Biolnform Servicer. 1995. P. 86-98.

[62] Voeikov V.L., Naletov V.I. // Biophotonics. Kluwer Academic Publishers. Dortrecht, The Netherlands. 1998. P. 93-108.

[63] Popp F.-A., Gu Q., Li K.-H. // Mod. Phys. Lett. B. 1994. V. 8. P. $1269-1296$.

[64] Quickenden T.I., Tilbury R.N. // J. Photochem. Photobiol. B. 1991. V. 8. P. 169-174.

[65] Slawinsky J. // Experientia. 1988. V. 44. № 7. P. 559-571.

[66] Vassiliev R.F. // Biochemiluminescence / Ed. by Zhuravlev A.I. M.: Nauka, 1985. P. 31-55.

[67] Wondrak G., Pier T., Tressl R. // J. Biolumin. Chemilumin. 1995. V. 10. P. 277-284.
[68] Voeikov V.L., Del Giudice E. // WATER: Multidiscip. Res. J. 2009. V. 1. P. 52-75. http://waterjournal.org/content/ view/45/64/

[69] Gudkov S.V., Lyakhov G.A., Pustovoy V.I., Shcherbakov I.A. // Phys. Wave Phenomen. 2019. V. 27. P. 141-144. doi $10.3103 / \mathrm{s} 1541308 \times 19020092$

[70] Владимиров Ю.А., Проскурнина Е.В. // Успехи биол. хим. 2009. T. 49. C. $341-388$.

[71] Брусков В.И., Гудков С.В., Чалкин С.Ф., Смирнова Е.Г,, Ягужсинский Л.С. // ДАН. 2009. Т. 425. № 6. С. 827-829.

[72] Belovolova L.V., Glushkov M.V., Vinogradova G.I., Vinogradov E.A. // Phys. Wave Phenom. 2008. V. 16. P. 292-299. doi 10.3103/S1541308X08040067

[73] Lobyshev V.I., Ryzhikov B.D., Shikhlinskaya Z.E. // Biophys. 1998. V. 43. P. 710-715.

[74] Беловолова Л.В., Глушков М.В., Виноградов Е.А. // Биофизика. 2014. Т. 59. № 4. С. 641-648.

[75] Брусков В.И., Масалимов Ж.К., Черников А.В. // ДАН. 2001. T. 381. № 2. С. 262-264.

[76] Брусков В.И., Масалимов Ж.К., Черников А.В. // ДАН 2002. T. 384. № 6. С. $821-824$.

[77] Belovolova L.V., Glushkov M.V., Vinogradov E.A. // Biophys. 2011. V. 5. P. $181-187$.

[78] Ванаг В.К. // УФН. 2004. Т. 174. С. 991-1010.

[79] Belovolova L.V., Glushkov M.V. // Phys. Wave Phenomen. 2017. V. 25. P. $1-11$.

[80] Fee J.A., Valentine J.S. // Superoxide and Superoxide Dismutases / Ed. by Michelson A.M., McCord J.M., Fridovich I. N.Y.: Acad. Press, 1977. P. 19-60.

[81] Joshi R., Ghanty T.K., Naumov S., Mukherjee T. // J. Phys. Chem. A. 2007. V. 111. P. 13590-13594. doi 10.1021/jp074194h

[82] Wardman P. // J. Phys. Chem. Ref. Data. 1989. V. 18. P. $1637-1755$. doi $10.1063 / 1.555843$

[83] Разумовский С.Д. Кислород - элементарные формы и свойства. М.: Химия, 1979.

[84] Bensasson R.V., Land E.J., Truscott T.G. Flash Photolysis and Pulse Radiolysis. Oxford: Pergamon Press, 1983.

[85] Афбанасьев И.Б. // Усп. химии. 1979. Т. 48. № 6. C. $977-1014$.

[86] Аристова Н.А., Иванова И.П., Трофимова С.В. // Препринт НИИЯФ МГУ № 2011-12/876. М., 2011.

[87] Владимиров Ю.А., Гаврилов В.Б, Лосев Г.М. // Журн. физ. хим. 1980. Т. 54. № 2. С. 504-506.

[88] Степуро И.И., Адамчук Р.И., Пилецкая Т.П. // Биохимия. 2000. Т. 65. № 12. С. $1645-1658$.

[89] Степуро И.И., Адамчук Р.И., Степуро В.И. // Биофизика. 2004. T. 49. № 5. С. $773-780$.

[90] Шинкаренко Н.В., Алесковский В.Б. // Усп.химии. 1981. T. 50. № 3. C. $406-428$.

[91] Филоненко Е.В., Серова Л.Г. // Biomed. Photon. 2016. V. 5. P. 26-37.

[92] Langford V.S., McKinley A.J., Quickenden T.I. // Acc. Chem. Res. 2000. V. 33. P. 665-671. doi 10.1021/ar990145e

[93] Matich J., Bakker M.G, Lennon D., Freeman C.G., Quickenden T.I. // J. Phys. Chem. 1993. V. 97. P. 10539-10553.

[94] Wentworth Jr.P. // Science. 2001. V. 293. P. 1806-1811. doi 10.1126/science.1062722

[95] Xu X., Muller R.P., Goddard W.A. // Proc. Nat. Acad. Sci. 2002. V. 99. P. 3376-3381. doi 10.1073/pnas.052710099 
[96] Воейков В.Л. // Сб. избранных трудов V Межд. Конгресса „Слабые и сверхслабые поля и излучения в биологии и медицине“. СПб., 2009. С. 98-107.

[97] Шарипов Г.Л. // Вестн. Башкирского унив. 2008. Т. 13. № 2. C. 240-253.

[98] Vanin A.F. // Nitric Oxide. 2009. V. 21. P. 1-13. http://www.sciencedirect.com/science/article/ pii/S1089860309000391

[99] Керр Джс., Калверт Ж., Демерджиан К. // Свободные радикалы в биологии / Под ред. Прайор У. М.: Мир, 1979. T. 2. C. $178-199$.

[100] Vallee P., Lafait J., Legrand L., Mentr. P., Monod M.-O., Thomas Y. // Langmuir. 2005. V. 21. P. 2293-2299 http://dx.doi.org/10.1021/la047916u

[101] Pashley R.M. // J. Phys. Chem. B. 2003. V. 107. P. 1714-1720. https://doi.org/10.1021/jp026744b

[102] Решетняк В., Блажсейовски Е. // Электрохимия органических соединений в начале XXI века. М., 2008. С. 6-55.

[103] Petrushanko I.Y., Lobyshev V.I. // Biophysics. 2001. V. 46. P. 389-401.

[104] Пастухов В.И., Морозов В.П. // Опт. и спектр. 2000. Т. 88. № 1. C. 41-44.

[105] Zhang C.-L., Popp F.-A. // Bioelectrodynamics and Biocommunication / Ed. by Ho M.-W., Popp F.-A., Warnke U.N.J.: World Scientific, 1994. P. 355-363.

[106] Attard P. // Adv. Coll. Int. Sci. 2003. V. 104. P. 75-91.

[107] Colic M., Morse D. // Colloids and Surfaces. A. 1999. V. 154. P. 167-174.

[108] Prevenslic T.V. // Ultrasonics. 2003. V. 41. P. 323-327.

[109] Бункин Н.Ф., Бункин Ф.В. // ЖЭТФ. 1992. Т. 101. № 2. C. 512-527.

[110] Абросимов В.К., Ефремов Л.С., Иванов Е.В., Панкратов Ю.П. // Журн. физ. хим. 2000. Т. 74. № 5. С. 854-857.

[111] Зелепухин В.Д., Зелепухин И.Д., Красноголовеи, В.В. // Хим. физ. 1993. Т. 12. № 7. С. $992-1005$.

[112] Емеи Б.Г. // ЖТФ. 2000. Т. 70. С. 134-135.

[113] Alheshibri M., Jing Qian, Jehannin M., Craig V.S.J. // Langmuir. 2016. V. 32. P. 11086-11100. doi 10.1021/acs.langmuir.6b02489

[114] Uchida T., Oshita S., Ohmori M., Tsuno T., Soejima K., Shinozaki S., Take Y., Mitsuda K. // Nanoscale Res. Lett. 2011. V. 6. P. 1. http://www.nanoscalereslett.com/content/6/1/295

[115] Agarwal A., Ng W.J., Liu Y. // Chemosphere. 2011. V. 84. P. $1175-1180$.

[116] Fujita T. // 7th Int. Symp. of Fine Bubble Technology. Sydney, Australia, 2016.

[117] Pauling L. // Science. 1961. V. 134. P. 15-21.

[118] Габуда С.П. Связанная вода. Факты и гипотезы. Наука, 1982.

[119] Воейков В.Л., Химич М.В. // Биофизика. 2002. Т. 47. № 1. C. $27-30$.

[120] Ляхов Г.А., Шипилов К.Ф. // Труды ИОФАН. 1997. Т. 54. C. $61-74$.

[121] Боярчук К.А., Ляхов Г.А., Свирко Ю.П., Суязов Н.В. // Труды ИОФАН. 1997. Т. 54. С. 130-154.

[122] Bunkin A.F., Lyakhov G.A., Nurmatov A.A., Suyazov N.V. // Труды ИОФАН. 1997. Т. 54. С. 5-26.

[123] Бункин А.Ф., Грачев В.И., Ляхов Г.А., Нурматов А.А. // Письма в ЖЭТФ. 1998. Т. 68. № 4. С. 266-268.
[124] Усанов Д.А., Скрипаль А.В., Усанов А.Д., Рытик А.П. Биофизические аспекты воздействия электромагнитных полей. Изд-во Сарат. ун-та, 2008.

[125] Беловолова Л.В., Глушков М.В. // Журн. физ. хим. 2019. T. 93. № 8. C. 1259-1267.

[126] Workman E.Y., Reynolds S.E. // Phys. Rev. 1950. V. 78. P. 254-259.

[127] Шибков А.А., Желтов М.А., Королев А.А. // Природа. 2000. № 9. C. 1. http://vivovoco.astronet.ru/ VV/JOURNAL/NATURE/09_00/RADIOICE.HTM

[128] Бараш Ю.С., Гинзбург В.Л. // УФН. 1984. Т. 143. № 3. C. $345-389$.

[129] Ширинкин С.В., Шапочников А.А., Волкова Т.О., Андриевский Г.В., Давыдовский А.Г., Закирова Л.Р., Круть У.А. // Научные ведомости. 2015. В. 31. С. 20-30.

[130] Stasheuski A.S., Galievsky V.A., Stupak A.P., Dzhagarov B.M., Choi M.J., Chun B.H., Jeong J.Y., Stepanov B.I. // Photochem. Photobiol. 2014. V. 90. P. 997-1003. doi 10.1111/php.12294

[131] Bagrov I.V., Kiselev V.M., Kislyakov I.M., Starodubtsev A.M., Burchinov A.N. // Opt. Spectr. 2015. V. 118. P. 440-448.

[132] Andrievsky G.V., Klochkov V.K., Bordyuh A.B., Dovbeshko G.I. // Chem. Phys. Lett. 2002. V. 364. P. 8-17. https//doi.org/10.1016/S0009-2614(02)01305-2

[133] Цундель Г. Гидратация и межмолекулярное взаимодействие. М.: Мир, 1972.

[134] Защепина Г.Н. Физические свойства и структура воды. МГУ, 1998.

[135] Richmon G.L. // Chem. Rev. 2002. V. 102. P. 2693-2724. doi 10.1021/cr0006876

[136] Sun Q., Guo Y. // J. Mol. Liq. 2016. V. 213. P. 28-32. $\mathrm{http} / / \mathrm{dx}$.doi.org/10.1016/j.molliq.2015.11.004

[137] Захаров С.Д., Иванов А.В. // Квант. электрон. 1999. Т. 29. № 3. C. 192-214.

[138] Блюменфельд Л.А. Проблемы биологической физики. М.: Наука, 1977.

[139] Krasnovsky A.A., Kozlov A.S. // J. Photochem. Photobiol. A. 2016. V. 329. P. $167-174$.

[140] Лаврик Н.Л., Бажсин Н.М. // Биофизика. 2011. Т. 56. № 3. C. 574-576.

[141] Datta D., Vaidehi N., Xu X., Goddard W.A. // Proc. Nat. Acad. Sci. USA. 2002. V. 99. P. 2636-2641. https //doi.org/10.1073/pnas.052709399

[142] Miyoshi N., Tomita G. // Z. Naturforsch. B. 1979. V. 34. P. 339-343.

[143] Woutersen S., Bakker H.J. // Nature. 1999. V. 402. P. 507-509. doi 10.1038/990058

[144] Bakker H.J., Nienhuys H.-K. // Science. 2002. V. 297. P. 587-590.

[145] Pollack G. The Fourth Phase of Water: Beyond Solid, Liquid, and Vapor. Ebner \& Sons, 2013.

[146] Gudkov S., Astashev M., Bruskov V., Kozlov V., Zakharov S., Bunkin N. // Entropy. 2014. V. 16. P. 6166-6185. doi 10.3390/e16116166

[147] Del Giudice E., Preparata G., Vitiello G. // Phys. Rev. Lett. 1988. V. 61. P. 1085-1088.

[148] Del Giudice E., Tedeschi A. // Electromagn. Biol. Med. 2009. V. 28. P. 46-52. doi 10.1080/15368370802708728

[149] Madl P., Del Giudice E., Voeikov V.L., Tedeschi A., Kolarž P., Gaisberger M., Hartl A. // Water. 2013. V. 5. P. 57-68.

[150] Belovolova L.V., Glushkov M.V., Timashev S.F. // J. Phys. Chem. A (Russ). 2015. V. 89. P. 1693-1703. 
[151] Tikhonov V.I., Volkov A.A. // Science. 2002. V. 296. P. 2363. doi 10.1126/science.1069513

[152] Voeikov V.L., Do Ming Ha, Mukhitova O.G., Vilenskaya N.D., Malishenko S.I., Bogachuk A.S. // Int. J. Design Nat. Ecodynam. 2010. V. 5. P. 30-38.

[153] До Минь Ха, Мухитова О.Г., Виленская Н.Д., Мальшенко С.И., Воейков В.Л. // Био-мед. радиоэлектрон. 2011. V. 2. P. $28-38$.

[154] Гусев В.А., Орлов В.А., Панов С.В. // Биофизика. 1998. T. 43. № 4. C. $745-750$.

[155] Головлев Е.Л. // Биофизика. 1998. Т. 43. № 4. С. 751-752.

[156] Тычинский В.П., Вайсс Д., Вышенская Т.В., Ягужинский Л.С., Никандров С.Л. // Биофизика. 2000. Т. 45. № 5. C. $870-877$. 